\title{
Modeling and synthesis of antiplasmodial chromones, chromanones and chalcones based on natural products of Kenya
}

\author{
MANYIM SCOLASTICA, ALBERT J. NDAKALA^, SOLOMON DERESE \\ Department of Chemistry, University of Nairobi. P.O. Box 30197-00100, Chiromo Campus, Nairobi, Kenya. Tel.: +254-20-4446138, \\ Fax.: +254-20-4446138, `email: andakala@uonbi.ac.ke
}

Manuscript received: 25 August 2017. Revision accepted: 30 December 2017.

\begin{abstract}
Scolastica M, Ndakala AJ, Derese S. 2018. Modeling and synthesis of antiplasmodial chromones, chromanones and chalcones based on natural products of Kenya. Biofarmasi J Nat Prod Biochem 16: 8-21. Despite numerous research that has been done on plants in Kenya, resulting in the isolation of thousands of natural products, data on these natural products are not systematically organized in a readily accessible form. This has urged the construction of a web-based database of natural products in Kenya. The database is named Mitishamba and is hosted at http://mitishamba.uonbi.ac.ke. The Mitishamba database was queried for chromones, chromanones, and chalcones and subjected to structure-based drug design using Fred's (OpenEye) docking utility program with the 1TV5 PDB structure, the PfDHODH receptor, to identify complex ligands that bind with the active site. Ligand-based drug design (Shape and electrostatics comparison) was also done on the ligands against query A77 1726 (38) (the ligand that is co-crystallized with PfDHODH receptor) using ROCS and EON programs, respectively, of OpenEye suite. There was a substantial similarity among the top-performing ligands in the docking studies with shape and electrostatic comparison that identified compounds of interest targeted for synthesis and antiplasmodial assay. In this study, a chromanone (7-hydroxy-2-(4-methoxyphenyl) chroman-4-one (48)) and two intermediate chalcones (2',4'-dihydroxy-4-methoxychalcone (45) and 2',4'-dihydroxy-4-chlorochalcone (47)), were synthesized and subjected to antiplasmodial assay. Among these substances, $\mathbf{4 5}$ showed vigorous activity, whereas $\mathbf{4 7}$ and $\mathbf{4 8}$ had moderate activity against the chloroquine-resistant K1 strain of $P$. falciparum with $\mathrm{IC}_{50}$ values of $4.56 \pm 1.66,17.62 \pm 5.94$, and $18.01 \pm 1.66 \mu \mathrm{g} / \mathrm{ml}$, respectively. Since the synthesized compounds showed antiplasmodial potential, there is a need for further computational refinement of these compounds to optimize their antiplasmodial activity.
\end{abstract}

Keywords: Antiplasmodial activity, chalcones, chromones, chromanones, web-based database

\section{INTRODUCTION}

Natural products have been the center of focus for many years as the primary source of new, more effective, and safer bioactive metabolites with therapeutic properties against various infectious diseases (Dike et al., 2012). The majority of the synthetic drugs used today are either inspired or derived from bioactive compounds in nature (Zhu et al., 2012). Thus, nature continues to be an essential source of new medicines.

The significance of bioactive compounds of natural origin is that they provide novel lead compounds or pharmacological agents for drug discovery. Medicinal plants have played a vital role in the treatment of malaria, as well as the development of antimalarial drugs. The bestknown potent antimalarial compound quinine was isolated from the bark of the Cinchona tree (Schlitzer 2007). Over the past decades, the discovery of artemisinin from Artemisia аппиа has boosted research on plants searching for new antimalarial lead compounds (Biamonte et al., 2013). Based on the historically high success rate of natural products, the diversity of chemical compounds found in nature continues to be an essential source of molecular templates in the search for novel antimalarial drugs (Nogueira and Lopes, 2011).

The African flora comprises a variety of medicinal plants, which the indigenous people have extensively utilized to treat various ailments. For example, in East Africa, there are close to 1,200 plant species with medicinal value (Kokwaro 2009). These plant species have been used to treat various diseases and ailments like malaria, typhoid, ulcers, skin diseases, diabetes, reproductive problems, aches, and pains. Multiple studies on medicinal plants of Kenya have led to the isolation of several bioactive compounds (Endale et al. 2012; Yenesew et al. 2003, 2004, 2005, 2009) with diverse structural scaffolds (Derese et al. 2003; Gumula et al. 2012; Omosa et al. 2010). Despite the enormous body of research existing on the natural products of Kenya, this information is not systematically organized in a readily accessible form. This is why a web-based searchable database of natural products in Kenya is developed in this study.

A searchable database of natural products of Kenya would be a source of templates, when combined with modeling, for the design and synthesis of drugs for treating various diseases. For example, chromone (1-benzopyran-4one), a core scaffold in flavonoids, has been identified to bind well with diverse receptors (Gaspar et al., 2011). This is due to the vast pharmacologically active compounds with this scaffold that have exhibited antimalarial, antibacterial, anticancer, anti-HIV, and anti-inflammatory activity. Chromone derivatives have also been found to act as kinase inhibitors by binding to benzodiazepine receptors (Keri et al., 2014). These attractive binding properties and biological 
activities make the chromone scaffold a template of interest for in silico design and synthesis of antiplasmodial compounds.

The objectives of this research were to (i) Develop a web-based in silico database of natural products of Kenya. (ii) Design antiplasmodial compounds based on chromone, chromanone, and chalcone scaffolds through virtual screening of the database against Plasmodium falciparum dihydroorotate dehydrogenase enzyme. (iii) Synthesize and evaluate the antiplasmodial activity of the promising chromones, chromanones, and chalcones from the virtual screening.

\section{MATERIALS AND METHODS}

\section{Database construction}

This study constructed a web-based in silico database of natural products in Kenya. Information on natural products was collected from different sources and processed to generate this web-based database.

\section{Data collection}

Information about compounds isolated from the natural products of Kenya was collected from various journal articles, review papers, theses, books of abstracts, and conference proceedings. The captured information was the structure of the compounds, common names, classes of the compounds, and biological activities (if available). It also included the plant species, family, parts of the plant where the compounds were extracted, places of the collection of the plant, and the reference of the source material.

\section{Data processing}

The data collected from the various sources was then captured in a Microsoft Excel spreadsheet. Accelrys Draw 4.1 SP1 software-academic version was used to draw the 2D chemical structures of the natural products collected from the literature. The mol2nam, a command-line utility of the Lexichem program (OpenEye Scientific Software), generated the compounds' IUPAC names and converted the 2D structures into SMILES files (1D format). Omegsa2, a command-line utility of the Omega program (OpenEye Scientific Software), was used to convert the 2D to $3 \mathrm{D}$ structures and generate the physicochemical properties of the compounds: polar surface area (PSA), molecular weight (MW), Merck molecular force field energy (MMFF), partition coefficient $(\log \mathrm{P})$, rotatable bonds, heavy atoms, hydrogen acceptors and hydrogen donors of the compounds. The data was visualized with the VIDA program (OpenEye Scientific Software) and exported into an initial MS excel spreadsheet. The data in the MS Excel spreadsheet was then transferred into the Discovery Studio 4.1visualizer, a product of Accelrys, where it was organized, and an SDF file was generated.

Generation of the web-based database of Kenya natural products

The Linux computer operating system was used to produce the web-based database of natural products from Kenya. The SDF file was exported into the local host database and then transferred to the web-based MySQL relational database using the command line. The information was stored in the MySQL database in normalized tables, where each compound was given a unique identification code. The creation of the database search engine was adapted from Nobert Heider's MolDBR6 (Haider 2010) software package based on the framework summarized in Figure 1. The software utilizes the checkmol and matchmol search engines (Haider 2010). Javascript editor JSME and Java molecule editor (JME) by Peter Ertl of Novartis (Bienfait and Ertl 2013) were used to enable users to search for compounds using structures. The search engine utilizes hypertext preprocessor (PHP) scripts and structured query language (SQL) to achieve its basic utility. The web-based database generated is hosted at http://mitishamba.uonbi.ac.ke.

\section{Preparation of the ligands and the receptor}

The ligands and the receptor were prepared for the virtual screening process.

\section{Preparation of the ligands}

The Mitishamba database was queried separately for the chromanone, chromone, and chalcone ligands, and the SDF file of the three hits was downloaded from http://mitishamba.uonbi.ac.ke. The three sdf files were combined and filtered using a filter program (OpenEye Scientific Software). The filter parameters used were based on the Lipinski rule of five (molecular weight $<500$, hydrogen bond donors $<5$, hydrogen bond acceptors $<10$, and $\log \mathrm{P}<5)($ Lipinski et al. 2012). The output was then saved as a zipped file (.oeb.gz).

Omega2 (OpenEye Scientific Software) was then used to generate 3D conformers of the filtered compounds using default parameters except for the number of conformers $($ maxconfs $=10)$ and stereochemistry (strict stereo $=$ false). The output was saved as a zipped file (.oeb.gz) and visualized using Vida (OpenEye Scientific Software).

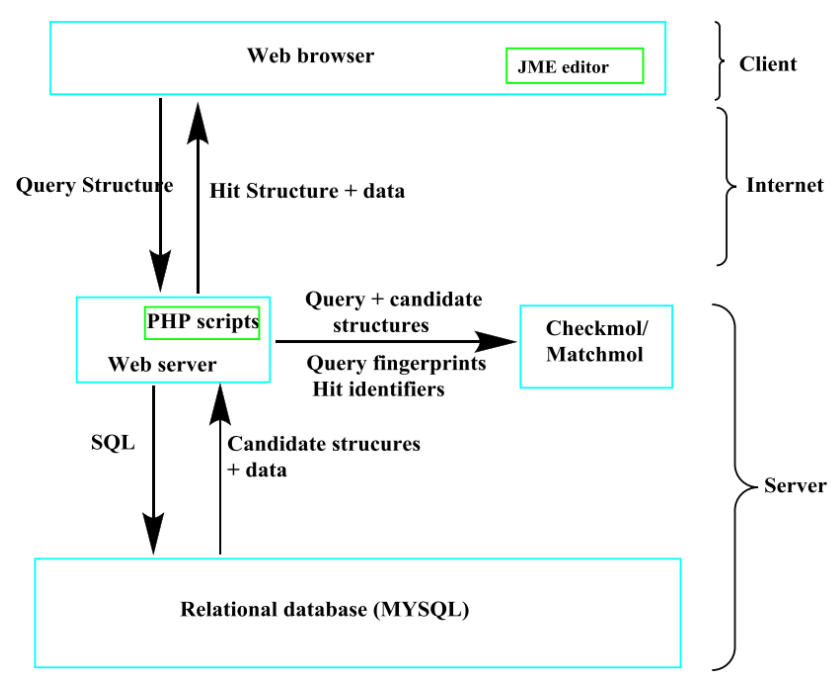

Figure 1. The architecture of the Mitishamba database search engine adapted from MOLDBR6 


\section{Receptor preparation}

The 1TV5 PDB structure of the Plasmodium falciparum dihydroorotate dehydrogenase $(P f \mathrm{DHODH})$ co-crystallized with A77 1726 (38) ligand, Figure 2, was obtained from the RCSB protein data bank at http://www.rcsb.org/pdb/explore.do?structureId=1tv5. The Make Receptor program (OpenEye Scientific Software) was used to define the active binding pocket of the target by selecting the ligand of interest $\mathbf{A 7 7} 1726$ (38) bound to the 1TV5 PDB structure. This was followed by creating a box that encloses the active site. Then the active site shape potential was created to define the outer and inner contours.<smiles>CC(O)=C(C#N)C(=O)Nc1ccc(C(F)(F)F)cc1</smiles>

38

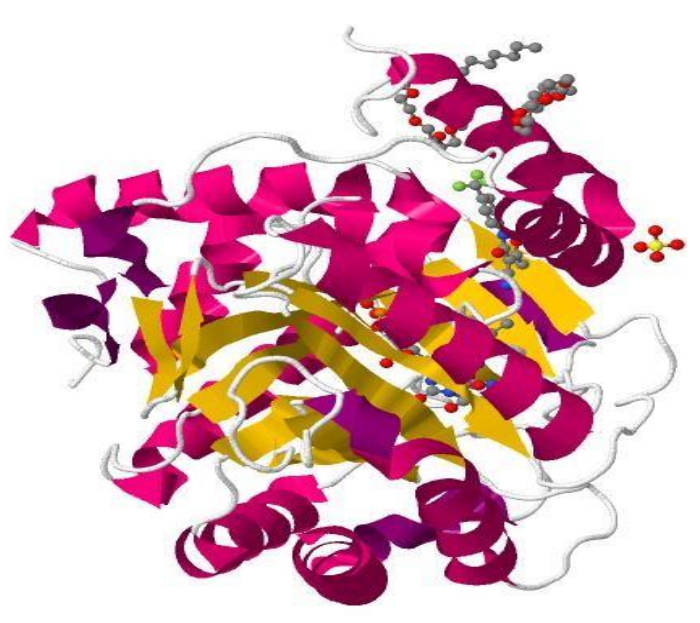

Figure 2. 3D Structure of $P f \mathrm{DHODH}$ with bound ligands

\section{Virtual screening}

The prepared ligands were then subjected to structurebased virtual screening against the prepared receptor and ligand-based virtual screening to identify promising antiplasmodial lead compounds.

\section{Structure-based virtual screening}

Fred (OEDocking, OpenEye Scientific Software) was used to carry out docking studies against the prepared $P f D H O D H$ receptor where the specified binding site contained the inhibitor (38). A docking study was done using the command line utility where the inputs were the zipped files of the ligands and the prepared PfDHODH receptor. At the same time, the output was a zipped file of the docked poses, which were then viewed using the Vida (OpenEye Scientific Software) visualizing program. The zipped file of the docked poses and the receptor were then used to generate a pdf document summarizing ligandreceptor interactions.

\section{Ligand-based virtual screening}

A shape and electrostatics similarity search was conducted using the validated query for ligand-based virtual screening.

Query validation. The inhibitor (38) bound to the 1TV5 PfDHODH receptor was chosen as the query molecule for use in shape and electrostatics similarity. A query validation run was done using the vROCS program (OpenEye Scientific Software) to determine whether the selected query was suitable for similarity search. The decoys and actives were obtained from the Database of Useful Decoys-Enhanced (DUD-E) http://dude.docking.org/target/pyrd. The databases of decoys and actives in the validation help establish whether the query is chosen to differentiate between the already known active and inactive (decoys) molecules against the target protein.

The receiver operating characteristic curve (ROC curve), together with its area under the curve (AUC) and the early enrichment values, are the statistical metrics generated by the vROCS program (OpenEye Scientific Software) that were used to validate the query (38). The validated question (38) was then used in ligand-based virtual screening of the chromones, chromanones, and chalcones to conduct shape matching and electrostatic similarity searches.

Shape similarity search. Using the validated query (38), vROCS (OpenEye Scientific Software) performed a shape similarity search. As generated by the Othe mega program, the 3D conformers of the ligands were overlaid on the query using the vROCS program, which employs the Gaussian shape overlap to score the ligands. The ligands are scored based on shape (Shape Tanimoto score) and color (Color Tanimoto score) and ranked based on the Tanimoto Combo score (shape and color).

Electrostatics similarity search. Using the validated query (38), electrostatics similarity studies on 3D conformers of the ligands were done using EON (OpenEye Scientific Software). EON aligns molecules on the query and calculates the electrostatic potential using the PoissonBoltzmann and Coulombic electrostatics tools. The molecules are scored regarding Poisson-Boltzmann electrostatics Tanimoto (ET pb), Coulombic electrostatics Tanimoto (ET_pb), and EON shape Tanimoto (EON_shape_tani). The ligands were then ranked using electrostatics Tanimoto combo (ET_combo), a combination of EON shape Tanimoto and Poisson-Boltzmann electrostatics Tanimoto (ET_pb).

The ranking of ligands based on structure and ligandbased virtual screening guided the identification of synthetically accessible chromones and chromanones targeted for synthesis.

\section{Synthesis of chromanones and chromones}

The approach for synthesizing chromanone and chromone-based lead compounds was based on retrosynthetic Figure 3. 
<smiles>O=C1CC(Br)Oc2cc(O)ccc21</smiles><smiles>C1=CCC1</smiles><smiles>O=C(C=C[Mg])c1ccc(O)cc1O</smiles><smiles>CC(=O)c1ccc(O)cc1O</smiles><smiles>Oc1cccc(O)c1</smiles><smiles>C1CC1</smiles><smiles>O=c1cc(Br)oc2cc(O)ccc12</smiles>

43

Figure 3. Retrosynthetic pathway to chromanones and chromones<smiles>CC(=O)c1ccc(O)cc1O</smiles>

40<smiles>COc1ccc(C=O)cc1</smiles>

44<smiles>CCO[N+](=O)[O-]</smiles>

45<smiles>CC(=O)c1ccc(O)cc1OCC(=O)O</smiles>

39

40

\section{General procedure}

Chemicals used in the synthesis were purchased from LOBA Chemie Laboratory reagents and fine chemicals. The purchased chemicals were of synthetic grade and did not need any purification. The solvents used in column and thin layer chromatography were distilled before use. The ${ }^{1} \mathrm{H}$ NMR spectra were obtained at 600 and $500 \mathrm{MHz}$ with TMS as an internal standard and deuterated dichloromethane and acetone as the solvents. Reactions were monitored on analytical TLC silica gel plates with a fluorescent indicator of $254 \mathrm{~nm}$. Purification was done using column chromatography on silica gel 60-120. Purification through recrystallization was done using methanol.

Procedure for synthesis of 2,4-dihydroxyacetophenone (40)

Anhydrous $\mathrm{ZnCl}_{2}$ (15 g, $\left.110 \mathrm{mmols}\right)$ was added to acetic acid $(30 \mathrm{~mL})$ and refluxed at $150{ }^{\circ} \mathrm{C}$. When all the $\mathrm{ZnCl}_{2}$ was almost dissolved, resorcinol (39) (10 g, 90

mmols) was added while stirring and refluxed for 3 hours. Then $50 \% \mathrm{HCl}(50 \mathrm{~mL})$ was added to break the $\mathrm{ZnCl}_{2}$ complex. A bright yellow precipitate formed as the mixture cooled to room temperature. This was further cooled in an ice bath and filtered. The residue was washed with $5 \% \mathrm{HCl}$ and recrystallized using $20 \% \mathrm{HCl}$ (Patil et al., 2012). Compound 40 was obtained as a yellow crystalline solid (4.6 g, 50\%), mp $146{ }^{\circ} \mathrm{C}:{ }^{1} \mathrm{H}$ NMR $\left(600 \mathrm{MHz}\right.$, Acetone- $\left.d_{6}\right)$ $\delta 12.77(s, 1 \mathrm{H}), 9.48(s, 1 \mathrm{H}), 7.79(d, J=8.40 \mathrm{~Hz}, 1 \mathrm{H}, \mathrm{C}-$ 6), $6.45(d d, J=2.40 \mathrm{~Hz}, 8.40 \mathrm{~Hz}, 1 \mathrm{H}, \mathrm{C}-5), 6.34(d, J=$ $2.40 \mathrm{~Hz}, 1 \mathrm{H}, \mathrm{C}-3), 2.57\left(s, 3 \mathrm{H}, \mathrm{OCH}_{3}\right) .{ }^{13} \mathrm{C} \mathrm{NMR}(151$ $\mathrm{MHz}$, Acetone- $\left.d_{6}\right) \delta 202.8(\mathrm{C}=\mathrm{O}), 164.9$ (C-4), 164.5 (C2), 133.5 (C-1), 113.4 (C-6), 107.7 (C-5), 102.4 (C-3), 25.5 $\left(\mathrm{CH}_{3}\right)$.

Procedure for synthesis of 2',4'-dihydroxy-4methoxychalcone (45)

$10 \% \mathrm{NaOH}(20 \mathrm{~mL})$ and $99 \%$ ethanol $(30 \mathrm{~mL})$ were mixed in a round-bottomed flask and cooled in an ice bath for 10 minutes. 4-Methoxybenzaldehyde (6 g, 44 mmols) was added while stirring, then 2, 4-dihydroxyacetophenone ( $3 \mathrm{~g}, 20 \mathrm{mmols}$ ) was added dropwise. The reaction mixture was left stirring and monitored using TLC until all the 2,4dihydroxyacetophenone was consumed; this took approximately 48 hours. The reaction mixture was poured over cold water and acidified using $20 \% \mathrm{HCl}$. Sodium bicarbonate was added while shaking until no bubbles were 
observed to remove the 4-methoxy benzoic acid. It was then transferred into a separatory funnel and extracted three times using ethyl acetate $(20 \mathrm{~mL})$. The organic layer was dried up using anhydrous $\mathrm{Na}_{2} \mathrm{SO}_{4}$, filtered, and concentrated under reduced pressure to provide a yellow precipitate which was purified using column chromatography $(5 \%$ ethyl acetate in hexane) and recrystallization (methanol). Compound 45 was obtained as a yellow solid (1.6 g, $30 \%)$, $\mathrm{mp} 186{ }^{\circ} \mathrm{C}:{ }^{1} \mathrm{H}$ NMR $\left(600 \mathrm{MHz}\right.$, Acetone- $\left.d_{6}\right) \delta 13.64(s$, $1 \mathrm{H}$, chelated hydroxyl $), 8.16(d, J=8.8 \mathrm{~Hz}, 1 \mathrm{H}, \mathrm{C}-6$ '), $7.86(m, 4 \mathrm{H}, \mathrm{C}-2, \mathrm{C}-3, \beta-\mathrm{C}$

and $(\alpha-\mathrm{C}), 7.05(d, 2 \mathrm{H}, \mathrm{C}-3$ and $\mathrm{C}-5), 6.50(d d, J=8.8$, $\left.2.2 \mathrm{~Hz}, 1 \mathrm{H}, \mathrm{C}-5^{\prime}\right), 6.40(d, J=2.2 \mathrm{~Hz}, 1 \mathrm{H}, \mathrm{C}-3$ ') $3.89(s$, $\left.3 \mathrm{H}, \mathrm{OCH}_{3}\right),{ }^{13} \mathrm{C} \mathrm{NMR}\left(150 \mathrm{MHz}\right.$, Acetone- $\left.d_{6}\right) \delta 191.9$ (C=O), 166.7 (C-4'), 164.7 (C-2'), 162.0 (C-4), 143.9 ( $\beta-\mathrm{C}), 132.5$ (C-1'), 130.7 (C-2), 130.7 (C-6), 128.0 (C-1), 118.2 ( $\alpha-\mathrm{C}), 114.4(\mathrm{C}-3), 114.4(\mathrm{C}-5), 113.6$ (C-6'), 107.8 (C-5'), $102.8\left(\mathrm{C}^{\prime} 3^{\prime}\right), 54.9\left(\mathrm{CH}_{3}\right)$.

\section{Procedure for synthesis of 2', 4'-dihydroxy-4- chlorochalcone (47)}

$10 \% \mathrm{NaOH}(10 \mathrm{~mL})$ and $95 \% \mathrm{EtOH}(10 \mathrm{~mL})$ were mixed in a flask and cooled in an ice bath for 10 minutes. 4-Chlorobenzaldehyde (6 g, $43 \mathrm{mmols}$ ) was added into the flask while stirring, and then 2'4-dihydroxyacetophenone (20 mmols) was added dropwise and stirred for 30 minutes. The reaction mixture was heated under reflux at $70^{\circ} \mathrm{C}$ and monitored using TLC until all the 2'4'dihydroxyacetophenone was consumed; this took 48 hours. The reaction mixture was poured over cold water and acidified using $20 \% \mathrm{HCl}$. Sodium bicarbonate was added while shaking until no bubbles were observed to remove 4chlorobenzoic acid. It was then transferred into a separatory funnel and extracted three times using ethyl acetate $(20 \mathrm{~mL})$. The organic layer was dried using anhydrous $\mathrm{Na} 2 \mathrm{SO} 4$, filtered, and concentrated under reduced pressure to purify a yellow precipitate using column chromatography (5\% ethyl acetate in hexane) and recrystallization (methanol). Light yellow crystals $(0.84 \mathrm{~g}$, $16 \%)$ were obtained: ${ }^{1} \mathrm{H}$ NMR $\left(500 \mathrm{MHz}\right.$, Acetone- $\left.d_{6}\right) \delta$ $13.44(s, 1 \mathrm{H}$, chelated hydroxyl $), 8.18(d, J=8.9 \mathrm{~Hz}, 1 \mathrm{H}$, C-6'), $8.00\left(d, J=15.5 \mathrm{~Hz}, 1 \mathrm{H}, \mathrm{H}_{\beta}\right), 7.91(d, J=8.4 \mathrm{~Hz}$, 2H, C-2 and C-6), $7.86\left(d, J=15.5 \mathrm{~Hz}, 1 \mathrm{H}, \mathrm{H}_{\alpha}\right), 7.52(d, J$ $=8.5 \mathrm{~Hz}, 2 \mathrm{H}, \mathrm{C}-3$ and C-5), $6.50(d d, J=8.9,2.4 \mathrm{~Hz}, 1 \mathrm{H}$, C-5'), $6.40\left(d, J=2.4 \mathrm{~Hz}, 1 \mathrm{H}, \mathrm{C}-3^{\prime}\right) .{ }^{13} \mathrm{C}$ NMR (126 MHz, Acetone- $\left.d_{6}\right) \delta 191.7(\mathrm{C}=\mathrm{O}), 166.8$ (C-4'), 165.1 (C-2'), 142.3 (C- $\beta$ ), 135.8 (C-4), 133.9 (C-1), 132.8 (C-6'), 130.3
(C-2), 130.3 (C-6), 129.0 (C-3), 129.0 (C-5), 121.6 (C- $\alpha)$, 113.6 (C-1'), 108.1 (C-5'), 102.9 (C-3').

Procedure for synthesis of 7-hydroxy-2-(4-methoxyphenyl) chroman-4-one (48)

Oxalic acid (1 g, 7.9 mmols) and 2',4'-dihydroxy-4methoxychalcone $(0.1 \mathrm{~g}, 0.37 \mathrm{mmols})$ were dissolved in ethanol $(10 \mathrm{~mL})$. The reaction mixture was heated at $80^{\circ} \mathrm{C}$ for 2 days. It was cooled to room temperature and poured over cold water and extracted three times with ethyl acetate $(20 \mathrm{~mL})$. The organic extract was dried using anhydrous $\mathrm{Na}_{2} \mathrm{SO}_{4}$ and concentrated under reduced pressure then purification was done using column chromatography $(5 \%$ ethyl acetate in hexane) and recrystallization (methanol). A yellow crystalline solid (29 mg, 29\%) was obtained: ${ }^{1} \mathrm{H}$ NMR (600 MHz, $\left.\mathrm{CD}_{2} \mathrm{Cl}_{2}\right) \delta 7.85(d, J=8.8 \mathrm{~Hz}, 2 \mathrm{H}, \mathrm{C}-2$ ' and C-6'), $7.44(d, J=8.6 \mathrm{~Hz}, 1 \mathrm{H}, \mathrm{C}-5), 6.99(d, J=8.8$ $\mathrm{Hz}, 2 \mathrm{H}, \mathrm{C}-3^{\prime}$ and C-5'), 6.59 (dd, $J=8.6,2.3 \mathrm{~Hz}, 1 \mathrm{H}, \mathrm{C}-$ 6), $6.49(d, J=2.3 \mathrm{~Hz}, 1 \mathrm{H}, \mathrm{C}-8), 5.46(\mathrm{dd}, \mathrm{J}=2.4,13.2 \mathrm{~Hz}$, $1 \mathrm{H}, \mathrm{H}-2), 3.86\left(s, 3 \mathrm{H}, \mathrm{OCH}_{3}\right), 3.09(d d, J=13.2,16.8$ $\left.\mathrm{Hz}, 1 \mathrm{H}, \mathrm{H}-3_{\text {eq }}\right), 2.81$ (dd, $\left.J=2.4,16.8 \mathrm{~Hz}, 1 \mathrm{H}, \mathrm{H}_{-3 \mathrm{ax}}\right) .{ }^{13} \mathrm{C}$ NMR (151 MHz, $\left.\mathrm{CD}_{2} \mathrm{Cl}_{2}\right) \delta 190.5(\mathrm{C}=\mathrm{O}), 163.6$ (C-7), 162.7 (C-4'), 160.0 (C-9), 130.9 (C-5), 129.1 (C-1'), 127.8 (C-2'), 127.8 (C-6'), 115.1 (C-10), 114.0 (C-3'), 114.0 (C5'), 110.3 (C-6), 103.2 (C-8), 79.7 (C-2), $55.3\left(\mathrm{OCH}_{3}\right)$, $44.0(\mathrm{C}-3)$.

\section{In vitro antiplasmodial bioassay}

In vitro antiplasmodial bioassay of compounds 45,47 , and 48 against chloroquine-resistant $\mathrm{K} 1$ and chloroquinesensitive 3D7 strains of Plasmodium falciparum was done using a non-radioactive assay technique (Heydenreich et al. 2011). This technique uses the fluorochrome referred to as SYBR Green I, which is a non-radioactive DNA dye that accurately depicts in vitro parasite replication. The parasites were cultured to attain $3-8 \%$ parasitemia. At the same time two-fold serial dilution of chloroquine (1.953$1000 \mathrm{ng} / \mathrm{mL})$, mefloquine $(0.488-250 \mathrm{ng} / \mathrm{mL})$ and test samples $(97.7-50,000 \mathrm{ng} / \mathrm{mL})$ were prepared on a 96 well plate. The culture-adapted $P$. falciparum was reconstituted to $1 \%$ parasitemia and added onto the plate containing the dose range of the reference drugs and test samples and incubated in the gas mixture $\left(5 \% \mathrm{CO}_{2}, 5 \% \mathrm{O}_{2}\right.$, and $90 \%$ $\mathrm{N}_{2}$ ) at $37{ }^{\circ} \mathrm{C}$. The assay was stopped after 72 hours by freezing at $-80{ }^{\circ} \mathrm{C}$ for 24 hours.<smiles>CC(=O)c1ccc(O)cc1O</smiles>

40<smiles>O=Cc1ccc(Cl)cc1</smiles>

46

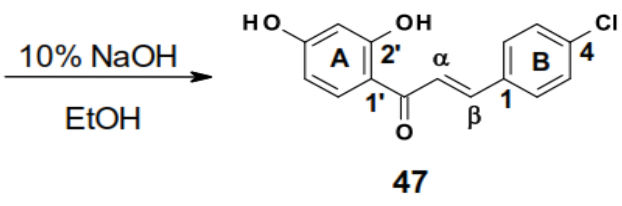

47

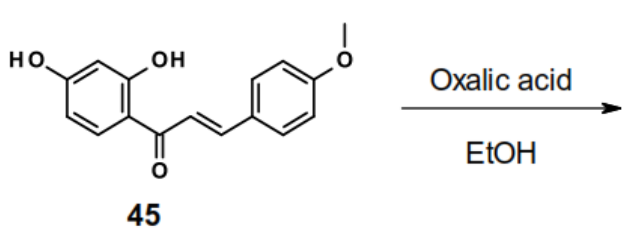<smiles>COc1ccc(C2CC(=O)c3ccc(O)cc3O2)cc1</smiles> 
Thawing was done, followed by the direct addition of the lysis buffer containing SYBR Green I (1×final concentration) into the plates and gently mixing the final solution with the Beckman Coulter Biomek 2000 automated laboratory workstation. Incubation of the plates was done for 5-15 minutes at room temperature in the dark. Parasite growth inhibition was quantified by measuring the per-well relative fluorescence units (RFU) of SYBR Green 1 dye using the Tecan Genios Plus (Tecan US, Inc., Durham, NC) with excitation and emission wavelengths of $485 \mathrm{~nm}$ and $535 \mathrm{~nm}$, respectively, and with the gain set at 60. Differential counts of relative fluorescence units (RFUs) were used in calculating $50 \%$ inhibition concentrations $\left(\mathrm{IC}_{50} \mathrm{~s}\right)$ ) for each drug using Prism 4.0 windows software (GraphPad Software, San Diego, CA). At least three separate determinations were carried out for each sample. Replicates had narrow data ranges hence presented as mean \pm SD.

\section{RESULTS AND DISCUSSION}

In this study, a web-based database of natural products of Kenya was developed, which was subjected to virtual screening to identify synthetically accessible chromones and chromanones for antiplasmodial assay.

\section{Database construction}

A web-based in silico database containing 1112 natural products of Kenya was constructed from data on natural products collected from theses, journal articles, books of abstracts, and conference proceedings. The information captured was the structure of the compounds (2D sketch files), common names, classes of the compounds and biological activities (if available). It also included the plant species, family, parts of the plant where the compounds were extracted, places of plant collection, and the reference of the source material.

Besides, the database contains physicochemical properties (polar surface area (PSA), molecular weight (MW), Merck molecular force field energy (MMFF), partition coefficient $(\log \mathrm{P})$, rotatable bonds, heavy atoms, hydrogen acceptors, and hydrogen donors) of the compounds. The database is named Mitishamba (a Kiswahili word meaning medicinal herbs) and is hosted at http:/mitishamba.uonbi.ac.ke.

\section{Features of the Mitishamba web-based database}

The Mitishamba web-based database has features for search (text, structure, and advanced search), browsing and downloading the entire database, and submitting structures, as shown in Figure 4.

Search options. The database has three search options: Text, structure, and advanced search. In-text search, users can search for structures using either trivial names or IUPAC names. For structure search, the database uses Peter Etrl Novartis (Haider 2010), Javascript molecule editor (JSME), or Java molecule editor (JME) for 2D structure input. The options are detected automatically on the users' browser, and one is used as a fallback in case either Javascript or Java feature is turned off. Optional parameters available for structure search include an exact match, substructure similarity search, and ratio similarity on a zero to hundred percent scale. Once an output is obtained, structures can be downloaded. The advanced search features allow users to search for compounds based on plant family and species.

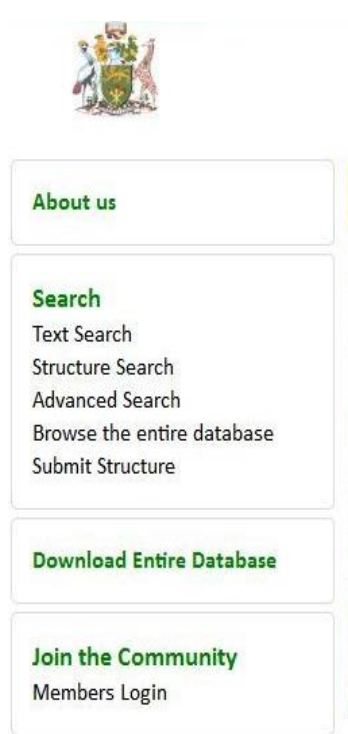

\section{Mitishamba Database A Database of Natural Products from Kenya for Drug Discovery...}
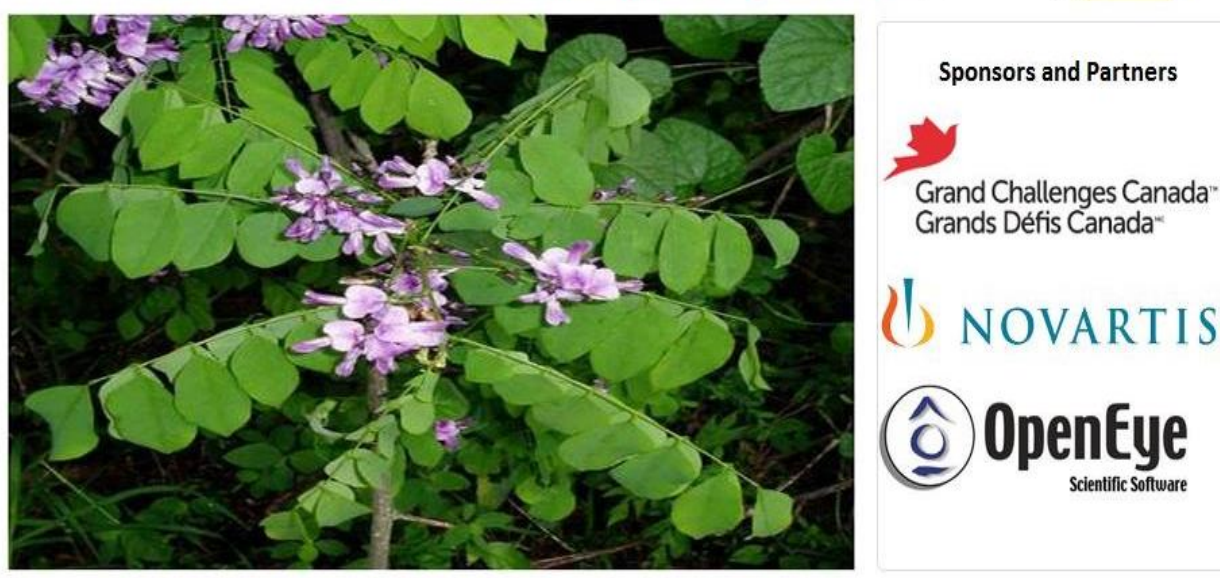

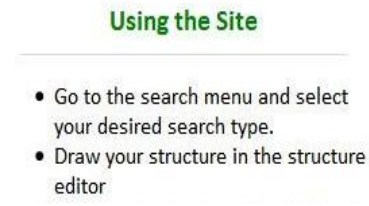

editor

\section{How to Download}

- Go to Text/Structure Search and key in your structure of interest

- Click the "View full Details" of the resulting Search

Figure 4. Homepage of the Mitishamba database 
Browse and download options. Users can also browse the structures in the entire database. Each structure can be downloaded individually as a mol file, or users can download the entire database in sdf, mol, smiles, or oeb formats.

Submitting structures. Users can submit their work on Kenya's natural products that have not been captured in the database. To submit structure, users upload a PDF document that contains the names of the natural products, family and botanical name of the source plant, place of collection of the plant, biological activities of the compounds, and appropriately referenced source of the publication.

\section{Virtual screening studies}

A search in the Mitishamba database identified 157 chromone, chromanone, and chalcone ligands. The ligands were then subjected to structure and ligand-based virtual screening.

\section{Ligand and receptor preparation}

The 157 ligands were filtered using a filter program based on Lipinski's rule of five (molecular weight $<500$, hydrogen bond donors $<5$, hydrogen bond acceptors $<10$, and Log P<5) (Lipinski et al. 2012), and this yielded 103 ligands. The 3D conformers of the 103 ligands were then generated using the omega program for use in both structure and ligand-based virtual screening.

The PDB file of the 1TV5 PfDHODH receptor with the bound ligand (38) was obtained from the RCSB protein data bank

http://www.rcsb.org/pdb/explore.do?structureId=1tv5 and prepared using Make Receptor program, Figure 5.

\section{Structure-based virtual screening studies}

Docking studies of the filtered ligands against the prepared PfDHODH receptor using the Fred program ranked the molecules using chemgausse4 docking scores (Kcal/mol). To ease the interpretation of the docking scores (raw data), z-scores were generated (Swann et al., 2011). Among the 103 ligands, the ligands with a z-score of one and above were 25 , Table 1 . The best scoring ligands were chromones, followed by chromanones and chalcones.

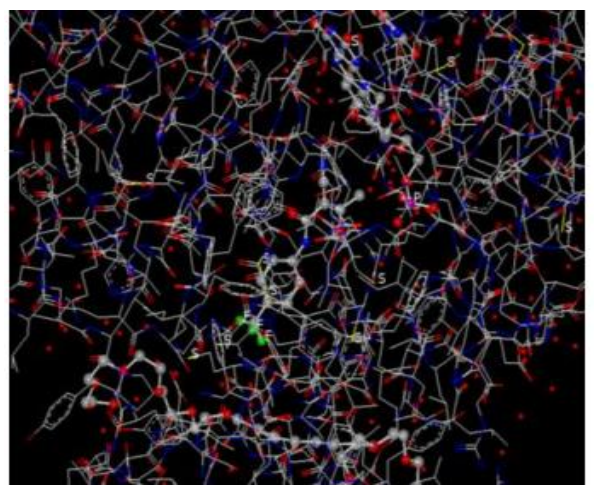

The interaction of the ligands with the PfDHODH receptor was studied and compared to the binding interaction of the inhibitor $(\mathbf{3 8})$. The inhibitor $(\mathbf{3 8})$ bound to the 1TV5 PfDHODH receptor shows hydrogen bonding interactions with three amino acid residues, ARG 265A, HIS 185A, and TRY 528A (Figure 6) (Hurt et al. 2006a,b).

Comparing the interaction of inhibitor (38) with those of the ligands, as expected, most of the ligands had at least one interaction with the three amino acid residues, Figure 7. Some ligands had other interactions; for example, Figure 8 shows interactions with TRY 168A and MET 536A, while Figure 9 shows interactions with GLY 181A. Other ligands showed further interactions with LEU 531, VAL 532A, LEU 172A, and CYS 184.

\section{Ligand-based virtual screening studies}

The shape and electrostatics of the 103 ligands were compared against a validated query of the inhibitor (38).

Query validation. The 3D structure of the 1TV5 PfDHODH inhibitor (38), Figure 10, was used as the query molecule for shape and electrostatic similarity. To determine whether query $\mathbf{3 8}$ is valid for shape and electrostatic similarity studies, vROCs Tanimoto combo scores (combination of shape and color scores) for the actives and decoys were used to plot the ROC curve (Figure 11). In the ROCs curve, Y-axis is the fraction of actives found, and $\mathrm{X}$-axis is the fraction of decoys found.

The statistical metrics derived from the ROC curve for query validation run are summarized in Table 2

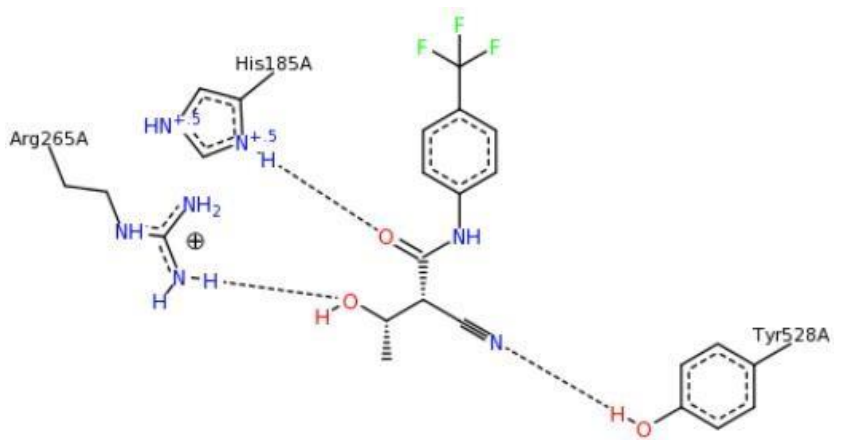

Figure 6. Hydrogen bonding interactions of the bound inhibitor (38) with amino acid residues of $P f \mathrm{DHODH}$

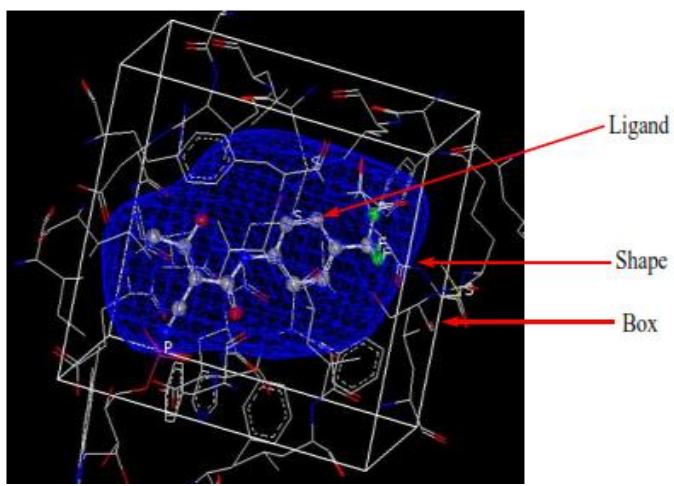

Figure 5. (A) 1TV5 PDB file (B) prepared 1TV5 Receptor showing the box enclosing the active site, the defined shape of the active site, and the bound ligand. 
Table 1. Docking and z-scores of ligands

\begin{tabular}{|c|c|c|c|}
\hline Smiles of Compounds & Class of ligand & $\begin{array}{c}\text { Docking score } \\
\text { (Kcal/mol) }\end{array}$ & $\begin{array}{l}Z \text { - } \\
\text { score }\end{array}$ \\
\hline$\overline{\mathrm{COc} 1 \mathrm{c}(=\mathrm{O}) \mathrm{c} 2 \mathrm{c}(\mathrm{cc}(\mathrm{cc} 2 \mathrm{oc} 1 \mathrm{c} 3 \mathrm{ccc}(\mathrm{c}(\mathrm{c} 3) \mathrm{O}) \mathrm{O}) \mathrm{O})[\mathrm{O}-]}$ & chromone & -14.8608 & 2 \\
\hline $\mathrm{COc} 1 \mathrm{cc}(\mathrm{c} 2 \mathrm{c}(\mathrm{c} 1) \mathrm{OC}(\mathrm{CC} 2=\mathrm{O}) \mathrm{c} 3 \operatorname{ccccc} 3)[\mathrm{O}-]$ & chromanone & -14.5211 & 2 \\
\hline $\mathrm{COc} 1 \mathrm{cc}(\mathrm{c} 2 \mathrm{c}(\mathrm{c} 1) \mathrm{OC}(\mathrm{CC} 2=\mathrm{O}) \mathrm{c} 3 \mathrm{ccccc} 3)[\mathrm{O}-]$ & chromone & -14.5211 & 2 \\
\hline $\operatorname{c1cc}(\operatorname{ccc} 1 \mathrm{c} 2 \mathrm{cc}(=\mathrm{O}) \mathrm{c} 3 \mathrm{c}(\mathrm{cc}(\operatorname{cc} 3 \mathrm{o} 2) \mathrm{O})[\mathrm{O}-]) \mathrm{O}$ & chromone & -14.5133 & 2 \\
\hline $\operatorname{COc} 1 \mathrm{cc}(\mathrm{c} 2 \mathrm{c}(=\mathrm{O}) \mathrm{cc}(\mathrm{oc} 2 \mathrm{c} 1) \mathrm{c} 3 \mathrm{ccc}(\mathrm{cc} 3) \mathrm{O})[\mathrm{O}-]$ & chromone & -14.3959 & 2 \\
\hline $\operatorname{COc} 1 \mathrm{c}(=\mathrm{O}) \mathrm{c} 2 \mathrm{c}(\mathrm{cc}(\operatorname{cc} 2 \mathrm{oc} 1 \mathrm{c} 3 \operatorname{ccc}(\operatorname{cc} 3) \mathrm{O}) \mathrm{O})[\mathrm{O}-]$ & chromone & -14.1036 & 1 \\
\hline $\operatorname{clccc}(\operatorname{cc} 1) \operatorname{cocc}(=\mathrm{O}) \mathrm{c} 3 \mathrm{c}(\mathrm{cc}(\mathrm{cc} 3 \mathrm{o} 2) \mathrm{O})[\mathrm{O}-]$ & chromanone & -13.9018 & 1 \\
\hline $\mathrm{COc} 1 \mathrm{cc}(\mathrm{c} 2 \mathrm{c}(\mathrm{c} 1) \mathrm{OC}(\mathrm{CC} 2=\mathrm{O}) \mathrm{c} 3 \mathrm{ccc}(\mathrm{cc} 3) \mathrm{O})[\mathrm{O}-]$ & chromone & -13.8635 & 1 \\
\hline $\mathrm{COc} 1 \mathrm{cc}(\mathrm{c} 2 \mathrm{c}(\mathrm{c} 1) \mathrm{OC}(\mathrm{CC} 2=\mathrm{O}) \mathrm{c} 3 \mathrm{ccc}(\mathrm{cc} 3) \mathrm{O})[\mathrm{O}-]$ & chromone & -13.8635 & 1 \\
\hline $\operatorname{clcc}(\mathrm{c}(\operatorname{cc} 1 \mathrm{c} 2 \mathrm{c}(\mathrm{c}(=\mathrm{O}) \mathrm{c} 3 \mathrm{c}(\mathrm{cc}(\mathrm{cc} 3 \mathrm{o} 2) \mathrm{O})[\mathrm{O}-])[\mathrm{O}-]) \mathrm{O}) \mathrm{O}$ & chromone & -13.8531 & 1 \\
\hline $\operatorname{c1cc}(\mathrm{c}(\operatorname{cc} 1 \mathrm{c} 2 \mathrm{c}(\mathrm{c}(=\mathrm{O}) \mathrm{c} 3 \mathrm{c}(\mathrm{cc}(\mathrm{cc} 3 \mathrm{o} 2) \mathrm{O})[\mathrm{O}-])[\mathrm{O}-]) \mathrm{O}) \mathrm{O}$ & chromone & -13.8531 & 1 \\
\hline $\operatorname{clcc}(\mathrm{c}(\mathrm{cc} 1 \mathrm{c} 2 \mathrm{cc}(=\mathrm{O}) \mathrm{c} 3 \mathrm{c}(\mathrm{cc}(\mathrm{cc} 3 \mathrm{o} 2) \mathrm{O})[\mathrm{O}-]) \mathrm{O}) \mathrm{O}$ & chromone & -13.8232 & 1 \\
\hline $\operatorname{clcc}(\operatorname{ccc} 1 \mathrm{c} 2 \mathrm{c}(\mathrm{c}(=\mathrm{O}) \mathrm{c} 3 \mathrm{c}(\mathrm{cc}(\mathrm{cc} 3 \mathrm{o} 2) \mathrm{O})[\mathrm{O}-])[\mathrm{O}-]) \mathrm{O}$ & chromone & -13.7642 & 1 \\
\hline $\mathrm{c} 1 \mathrm{c}(\mathrm{cc}(\mathrm{c}(\mathrm{c} 1 \mathrm{O}) \mathrm{O}) \mathrm{O}) \mathrm{c} 2 \mathrm{c}(\mathrm{c}(=\mathrm{O}) \mathrm{c} 3 \mathrm{c}(\mathrm{cc}(\mathrm{cc} 3 \mathrm{o} 2) \mathrm{O})[\mathrm{O}-])[\mathrm{O}-]$ & chromone & -13.7514 & 1 \\
\hline $\operatorname{COc} 1 \operatorname{ccc}(\mathrm{c}(\mathrm{c} 1) \mathrm{O}) \mathrm{C}(=\mathrm{O}) \mathrm{C}=\mathrm{Cc} 2 \operatorname{cccc} 2$ & chalcone & -13.6169 & 1 \\
\hline $\operatorname{c1ccc}(\operatorname{cc} 1) \mathrm{C} 2 \mathrm{CC}(=\mathrm{O}) \mathrm{c} 3 \mathrm{c}(\mathrm{cc}(\mathrm{cc} 3 \mathrm{O} 2) \mathrm{O})[\mathrm{O}-]$ & chromanone & -13.5869 & 1 \\
\hline $\operatorname{COc} 1 \mathrm{cc}(\operatorname{cc}(\operatorname{c1C}(=\mathrm{O}) \mathrm{C}=\mathrm{Cc} 2 \operatorname{ccc} c 2) \mathrm{O}) \mathrm{O}$ & chalcone & -13.55 & 1 \\
\hline $\mathrm{COc} 1 \mathrm{cc}(\mathrm{c} 2 \mathrm{c}(\mathrm{c} 1) \mathrm{oc}(\mathrm{c}(\mathrm{c} 2=\mathrm{O}) \mathrm{OC}) \mathrm{c} 3 \mathrm{ccc}(\mathrm{cc} 3) \mathrm{O})[\mathrm{O}-]$ & chromone & -13.5402 & 1 \\
\hline $\mathrm{COc} 1 \mathrm{cc}(\mathrm{c}(\mathrm{c} 2 \mathrm{c} 1 \mathrm{c}(=\mathrm{O}) \mathrm{cc}(\mathrm{o} 2) \mathrm{c} 3 \operatorname{cccc} 3) \mathrm{OC}) \mathrm{O}$ & chromone & -13.4887 & 1 \\
\hline $\mathrm{COc} 1 \mathrm{cc} 2 \mathrm{c}(\mathrm{c}(\mathrm{c} 1 \mathrm{OC})[\mathrm{O}-]) \mathrm{C}(=\mathrm{O}) \mathrm{CC}(\mathrm{O} 2) \mathrm{c} 3 \mathrm{ccc}(\mathrm{cc} 3) \mathrm{O}$ & chromanone & -13.4786 & 1 \\
\hline $\operatorname{COc} 1 \mathrm{cc}(\mathrm{c}(\mathrm{c}(\mathrm{c} 1) \mathrm{O}) \mathrm{C}(=\mathrm{O}) \mathrm{C}=\mathrm{Cc} 2 \operatorname{cccc} 2) \mathrm{O}$ & chalcone & -13.4599 & 1 \\
\hline $\mathrm{COc} 1 \mathrm{ccc}(\mathrm{cc} 1) \mathrm{c} 2 \mathrm{c}(\mathrm{c}(=\mathrm{O}) \mathrm{c} 3 \mathrm{c}(\mathrm{cc}(\mathrm{cc} 3 \mathrm{o} 2) \mathrm{O})[\mathrm{O}-]) \mathrm{OC}$ & chromone & -13.4357 & 1 \\
\hline $\mathrm{COc} 1 \mathrm{c}(\mathrm{cc} 2 \mathrm{c}(\mathrm{c} 1[\mathrm{O}-]) \mathrm{c}(=\mathrm{O}) \mathrm{c}(\mathrm{c}(\mathrm{o} 2) \mathrm{c} 3 \mathrm{ccc}(\mathrm{cc} 3) \mathrm{O})[\mathrm{O}-]) \mathrm{O}$ & chromone & -13.3051 & 1 \\
\hline $\operatorname{c1ccc}(\operatorname{cc} 1) \operatorname{c} 2 \mathrm{cc}(=\mathrm{O}) \mathrm{c} 3 \mathrm{ccc} 4 \mathrm{c}(\mathrm{c} 3 \mathrm{o} 2) \operatorname{cco} 4$ & chromone & -13.2924 & 1 \\
\hline $\operatorname{COc} 1 \mathrm{ccc}(\mathrm{cc} 1) \mathrm{c} 2 \mathrm{cc}(=\mathrm{O}) \mathrm{c} 3 \mathrm{c}(\mathrm{cc}(\mathrm{cc} 3 \mathrm{o} 2) \mathrm{O})[\mathrm{O}-]$ & chromone & -13.2169 & 1 \\
\hline
\end{tabular}

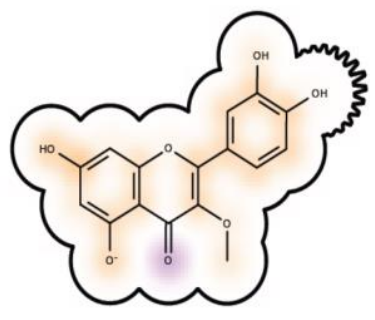

$\mathbf{A}$

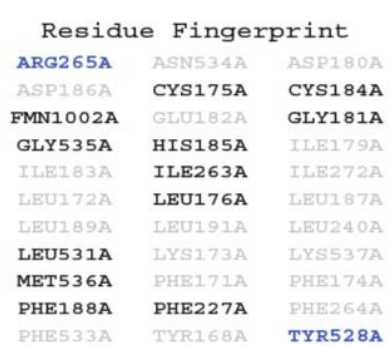

B

Figure 7. (A) ligand (B) amino acid residues that interacted (blue are donors)

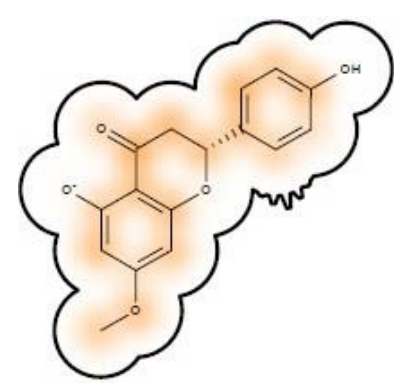

A
Residue F1ngerprint ARE265A A.SN534A ASP180A ASPIB6A CYS175A CYS184A FMNI002A GLU182A GLY181A GLY535A H표185A TIE179교 ILB183A ILE263A TLP272A LEU172A LEU176A LEU187 LEUI89A IEUI91A LEU2407 LEU531A LYS173A LYS537 A UET536A PHE171A PHE174A PHE188A PHE227A PHE264Z PHR533A TYR168A TYR528A VAL532A

\section{B}

Figure 8. (A) ligand (B) amino acid residues that interacted (blue are donors, red are acceptors)

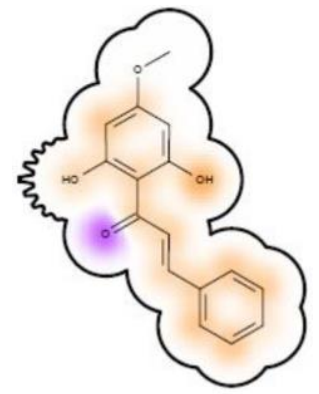

A

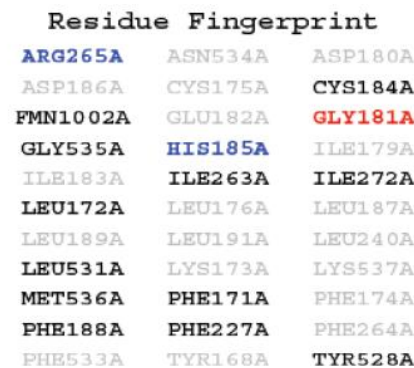

B
Figure 9. (A) ligand (B) amino acid residues that interacted (blue are donors, red are acceptors, and black is by contact)

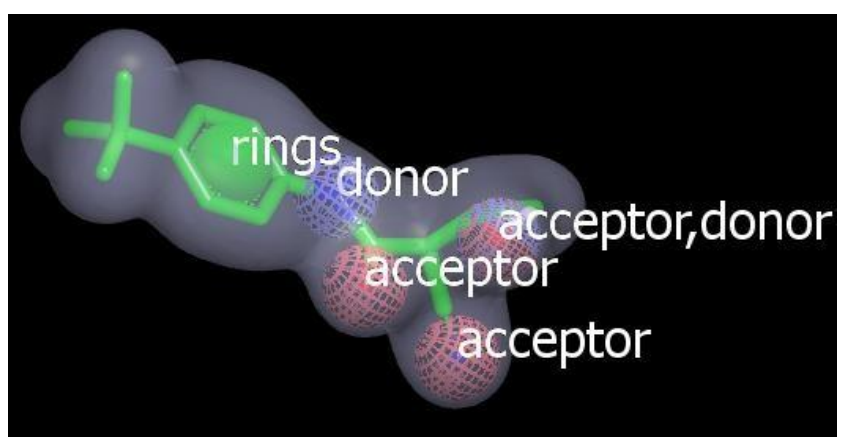

Figure 10. 3D structure of the query molecule (38) showing shape contour and color and shape atoms 


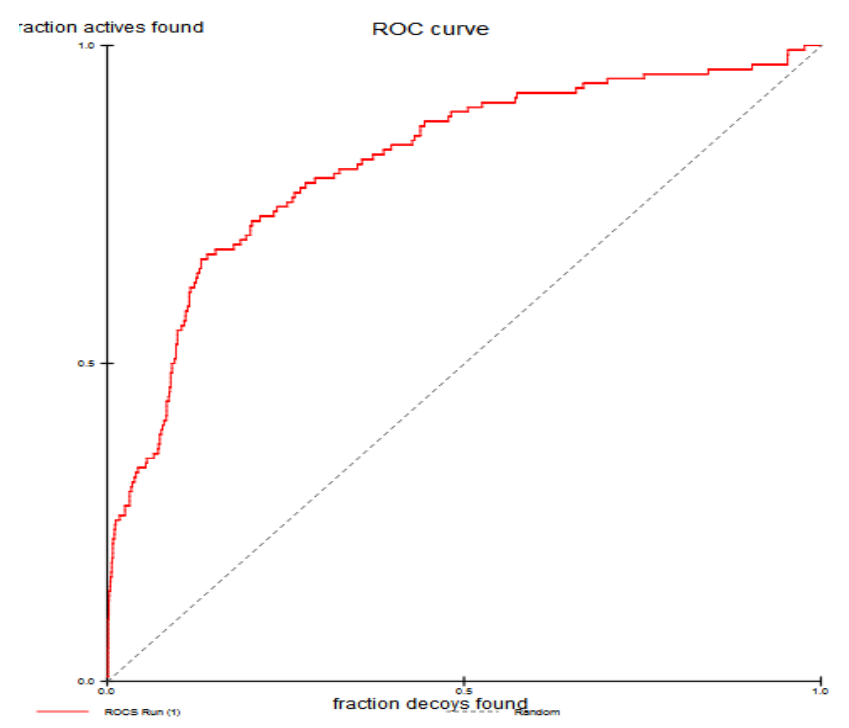

Figure 11. ROC curve for the query

Table 2. Query validation run statistical metrics

\begin{tabular}{ll}
\hline Statistical metrics & Values \\
\hline AUC & 0.813 \\
$0.5 \%$ enrichment & 31.399 \\
$1.0 \%$ enrichment & 22.320 \\
$2.0 \%$ enrichment & 12.589 \\
\hline
\end{tabular}

The area below the curve (AUC) is the probability that a randomly chosen active has a higher score than a randomly selected inactive. A highly selective query has $0.8<$ AUC $<1.0$ (Jain and Nicholls 2008). Since the AUC for query 38 is 0.813 , the query is highly particular. Table 2 indicates that the early enrichment values decrease with an increase in the percentage of the decoys. Initial enrichment values refer to the fractions of the actives at the particular portion of the decoys (Senger et al., 2003). Therefore, the AUC and early enrichment values indicate that query $\mathbf{3 8}$ is selective and hence suitable and valid for use in both shape and electrostatics similarity studies.

The shape and electrostatics similarity studies. A shape similarity search was done on the 3D conformers of the 103 ligands to compare the shape of these ligands to the shape of the validated query. The ligands were ranked based on Tanimoto combo scores, and the results are summarized in Table 3. Similarly, an electrostatic similarity comparison between the validated query and the 3D conformers of the 103 ligands was done and ranked using the electrostatic Tanimoto score (ET score), Table 3.

The ROCS Tanimoto combo scores and the EON electrostatic tanimoto scores were combined into the total tanimoto score. The total tanimoto score was then used to calculate $\mathrm{z}$ scores which were used to identify the top 29 ligands, Table 3. Like structure-based virtual screening studies (Table 1), ligand-based virtual screening identified chromones as the most virtually active, followed by chromanones and chalcones.

\section{Selection of compounds for synthesis}

Generally, both structure and ligand-based virtual screening studies identified chromones (flavones) as the best inhibitors of PfDHODH, followed by chromanones (flavanones) and chalcones. Although the specific ranking order varies, the general trend remains the same. The ranking of ligands based on structure and ligand-based virtual screening guided the identification of synthetically accessible chromones and chromanones targeted for synthesis.

\section{Synthesis of chromanones and chromones}

The approach for synthesizing chromanone and chromone-based lead compounds was based on retrosynthetic Figure 12. The starting material for the synthesis was resorcinol (39), which was acylated and then subjected to Aldol condensation and cyclization to access the target chromanones (42) and chromones (43).

Synthesis of 2,4-dihydroxyacetophenone (40). 2,4Dihydroxyacetophenone (40) was synthesized through Friedel Craft acylation of resorcinol (39) using acetic acid in the presence of $\mathrm{ZnCl}_{2}$ as the Lewis acid (Figure 13) (Patil et al. 2012).

The product was obtained as a yellow crystalline solid with a $50 \%$ yield. The structure of the product was determined using ${ }^{1} \mathrm{H}$ and ${ }^{13} \mathrm{C}$ NMR. The ${ }^{1} \mathrm{H}$ NMR signals of an acetoxymethyl at $\delta 2.57(s, 3 \mathrm{H})$, a chelated hydroxyl $(\delta 12.77(s, 1 \mathrm{H}))$, a hydroxyl $(\delta 9.48(s, 1 \mathrm{H}))$ and three mutually coupled aromatic protons at $\delta 7.79(d, J=8.40$ $\mathrm{Hz}, 1 \mathrm{H}), 6.45$ ( $d d, J=2.40,8.80 \mathrm{~Hz}, 1 \mathrm{H}), 6.34(d, J=2.40$ $\mathrm{Hz}, 1 \mathrm{H})$ are consistent with literature (Patil et al. 2012). The ${ }^{13} \mathrm{C}$ NMR signals at $\delta 202.8(\mathrm{C}=\mathrm{O}), 164.9(\mathrm{C}-4), 164.5$ (C-2) 133.5 (C-1), 113.4 (C-6), 107.7 (C-5), 102.4 (C-3), $25.5\left(\mathrm{CH}_{3}\right)$ are also consistent with literature (Patil et al. 2012).

Synthesis of 2',4'-dihydroxy-4-methoxychalcone (45). 2',4'-Dihydroxy-4-methoxychalcone (45) was synthesized through base-catalyzed Aldol condensation of 2,4-dihydroxyacetophenone (40) and 4methoxybenzaldeyde (44). The product was obtained as yellow crystals in $30 \%$ yield. The formation of 2',4'dihydroxy-4-methoxychalcone (45) was found to be slow (48 hrs), which could be attributed to the presence of two hydroxyl groups on the acetophenone (40). Under necessary conditions, the phenolic protons are picked, thus increasing the electron density in the system and reducing the electrophilicity of the carbonyl group, thereby lowering the acidity of the methyl hydrogens (Figure 14).

The ${ }^{1} \mathrm{H}$ NMR signals for compound $\mathbf{4 5}$ were similar to those of compound $\mathbf{4 0}$ except for incorporating a methoxy $\delta 3.89\left(s, 3 \mathrm{H}, \mathrm{OCH}_{3}\right)$. In the ${ }^{13} \mathrm{C} \mathrm{NMR}$, the signal for the carbonyl is more shielded ( $\delta$ 191.9) compared to the starting material ( $\delta$ 202.8), consistent with an $\alpha \beta$ unsaturated carbonyl system $(118.2(\alpha-\mathrm{C})$ and $143.9(\beta-\mathrm{C}))$ as would be expected from an Aldol condensation product. 
Table 3. Ligand-based virtual screening results

\begin{tabular}{|c|c|c|c|c|}
\hline Smiles of compounds & Tanimoto combo & ET combo & Total & Z-score \\
\hline$\overline{c 1 c c}(\mathrm{c}(\mathrm{cc} 1 \mathrm{c} 2 \mathrm{c}(\mathrm{c}(=\mathrm{O}) \mathrm{c} 3 \mathrm{ccc}(\mathrm{cc} 3 \mathrm{o} 2) \mathrm{O})[\mathrm{O}-]) \mathrm{O}) \mathrm{O}$ & 0.955 & 0.754 & 1.709 & 2 \\
\hline $\operatorname{clcc}(\mathrm{c}(\operatorname{cc} 1 \mathrm{c} 2 \mathrm{c}(\mathrm{c}(=\mathrm{O}) \mathrm{c} 3 \mathrm{c}(\mathrm{cc}(\mathrm{cc} 3 \mathrm{o} 2) \mathrm{O})[\mathrm{O}-])[\mathrm{O}-]) \mathrm{O}) \mathrm{O}$ & 0.941 & 0.754 & 1.695 & 2 \\
\hline $\operatorname{clcc}(\mathrm{c}(\operatorname{cc} 1 \mathrm{c} 2 \mathrm{cc}(=\mathrm{O}) \mathrm{c} 3 \mathrm{c}(\mathrm{cc}(\mathrm{cc} 3 \mathrm{o} 2) \mathrm{O})[\mathrm{O}-]) \mathrm{O}) \mathrm{O}$ & 0.942 & 0.741 & 1.683 & 2 \\
\hline $\mathrm{COc} 1 \mathrm{ccc}(\mathrm{cc} 1 \mathrm{O})[\mathrm{C} @ \mathrm{H}] 2[\mathrm{C} @ @ \mathrm{H}](\mathrm{C}(=\mathrm{O}) \mathrm{c} 3 \mathrm{c}(\mathrm{cc}(\mathrm{cc} 3 \mathrm{O} 2) \mathrm{OC})[\mathrm{O}-]) \mathrm{O}$ & 0.946 & 0.706 & 1.652 & 2 \\
\hline COc1 $1 \mathrm{ccc}(\operatorname{cc} 1) \mathrm{c} 2 \mathrm{cc}(=\mathrm{O}) \mathrm{c} 3 \mathrm{c}(\mathrm{cc}(\mathrm{cc} 3 \mathrm{o} 2) \mathrm{O})[\mathrm{O}-]$ & 0.888 & 0.755 & 1.643 & 2 \\
\hline $\operatorname{COc} 1 \mathrm{ccc}(\mathrm{cc} 1 \mathrm{O}) \mathrm{c} 2 \mathrm{c}(\mathrm{c}(=\mathrm{O}) \mathrm{c} 3 \mathrm{c}(\mathrm{o} 2) \mathrm{cc}(\mathrm{c}(\mathrm{c} 3[\mathrm{O}-]) \mathrm{O}) \mathrm{O})[\mathrm{O}-]$ & 0.922 & 0.706 & 1.628 & 2 \\
\hline $\mathrm{COc} 1 \mathrm{cc}(\mathrm{c} 2 \mathrm{c}(=\mathrm{O}) \mathrm{cc}(\mathrm{oc} 2 \mathrm{c} 1) \mathrm{c} 3 \mathrm{ccc}(\mathrm{c}(\mathrm{c} 3) \mathrm{OC}) \mathrm{O})[\mathrm{O}-]$ & 0.903 & 0.711 & 1.614 & 1 \\
\hline $\operatorname{COc} 1 \mathrm{ccc}(\mathrm{cc} 1) \mathrm{c} 2 \mathrm{cc}(=\mathrm{O}) \mathrm{c} 3 \mathrm{c}(\mathrm{cc}(\mathrm{cc} 3 \mathrm{o} 2) \mathrm{OC})[\mathrm{O}-]$ & 0.875 & 0.732 & 1.607 & 1 \\
\hline $\operatorname{COc} 1 \mathrm{c}(=\mathrm{O}) \mathrm{c} 2 \mathrm{c}(\mathrm{cc}(\mathrm{cc} 2 \mathrm{oc} 1 \mathrm{c} 3 \mathrm{ccc}(\mathrm{c}(\mathrm{c} 3) \mathrm{O}) \mathrm{O}) \mathrm{O})[\mathrm{O}-]$ & 0.897 & 0.707 & 1.604 & 1 \\
\hline $\operatorname{COc} 1 \mathrm{cc}(\mathrm{c} 2 \mathrm{c}(\mathrm{c} 1)) \mathrm{oc}(\mathrm{c}(\mathrm{c} 2=\mathrm{O})[\mathrm{O}-]) \mathrm{c} 3 \mathrm{ccc}(\mathrm{c}(\mathrm{c} 3) \mathrm{OC}) \mathrm{O})[\mathrm{O}-]$ & 0.889 & 0.71 & 1.599 & 1 \\
\hline $\mathrm{COc} 1 \mathrm{ccc}(\mathrm{cc} 1 \mathrm{O}) \mathrm{c} 2 \mathrm{c}(\mathrm{c}(=\mathrm{O}) \mathrm{c} 3 \mathrm{c}(\mathrm{cc}(\mathrm{cc} 3 \mathrm{o} 2) \mathrm{OC})[\mathrm{O}-]) \mathrm{OC}$ & 0.92 & 0.674 & 1.594 & 1 \\
\hline $\mathrm{c} 1 \mathrm{c}(\mathrm{cc}(\mathrm{c}(\mathrm{c} 1 \mathrm{O}) \mathrm{O}) \mathrm{O}) \mathrm{c} 2 \mathrm{c}(\mathrm{c}(=\mathrm{O}) \mathrm{c} 3 \mathrm{c}(\mathrm{cc}(\mathrm{cc} 3 \mathrm{o} 2) \mathrm{O})[\mathrm{O}-])[\mathrm{O}-]$ & 0.893 & 0.698 & 1.591 & 1 \\
\hline $\operatorname{clcc}(\operatorname{ccc} 1 \mathrm{c} 2 \mathrm{cc}(=\mathrm{O}) \mathrm{c} 3 \mathrm{c}(\mathrm{cc}(\mathrm{cc} 3 \mathrm{o} 2) \mathrm{O})[\mathrm{O}-]) \mathrm{O}$ & 0.854 & 0.73 & 1.584 & 1 \\
\hline $\mathrm{CC} 1(\mathrm{C}=\mathrm{Cc} 2 \mathrm{cc}(\mathrm{cc}(\mathrm{c} 2 \mathrm{O} 1) \mathrm{O})[\mathrm{C} @ @ \mathrm{H}] 3 \mathrm{CC}(=\mathrm{O}) \mathrm{c} 4 \mathrm{c}(\mathrm{cc}(\mathrm{cc} 4 \mathrm{O} 3) \mathrm{O})[\mathrm{O}-]) \mathrm{C}$ & 0.836 & 0.732 & 1.568 & 1 \\
\hline $\operatorname{COc} 1 \mathrm{ccc}(\operatorname{cc} 1 \mathrm{OC}) \mathrm{c} 2 \mathrm{c}(\mathrm{c}(=\mathrm{O}) \mathrm{c} 3 \mathrm{c}(\mathrm{cc}(\mathrm{cc} 3 \mathrm{o} 2) \mathrm{OC})[\mathrm{O}-]) \mathrm{OC}$ & 0.873 & 0.681 & 1.554 & 1 \\
\hline $\operatorname{COc} 1 \mathrm{cc}(\mathrm{c} 2 \mathrm{c}(=\mathrm{O}) \mathrm{cc}(\mathrm{oc} 2 \mathrm{c} 1) \mathrm{c} 3 \mathrm{ccc}(\mathrm{cc} 3) \mathrm{O})[\mathrm{O}-1$ & 0.839 & 0.707 & 1.546 & 1 \\
\hline $\mathrm{COc} 1 \mathrm{ccc}(\mathrm{cc} 1)[\mathrm{C} @ \mathrm{H}] 2 \mathrm{CC}(=\mathrm{O}) \mathrm{c} 3 \mathrm{c}(\mathrm{ccc}(\mathrm{c} 3 \mathrm{O} 2) \mathrm{OC})[\mathrm{O}-]$ & 0.844 & 0.698 & 1.542 & 1 \\
\hline $\mathrm{COc} 1 \mathrm{cc}(\operatorname{ccc} 1 \mathrm{O}) \mathrm{c} 2 \mathrm{c}(\mathrm{c}(=\mathrm{O}) \mathrm{c} 3 \mathrm{c}(\mathrm{cc}(\mathrm{c}(\mathrm{c} 3 \mathrm{o} 2) \mathrm{OC}) \mathrm{O})[\mathrm{O}-])[\mathrm{O}-]$ & 0.842 & 0.685 & 1.527 & 1 \\
\hline $\operatorname{clccc}(\operatorname{cc} 1) \mathrm{c} 2 \mathrm{cc}(=\mathrm{O}) \mathrm{c} 3 \mathrm{c}(\mathrm{cc}(\mathrm{cc} 3 \mathrm{o} 2) \mathrm{O})[\mathrm{O}-]$ & 0.83 & 0.686 & 1.516 & 1 \\
\hline COc1ccc $(\operatorname{cc} 1) c 2 c(c(=0) c 3 c(\operatorname{cc}(\operatorname{cc} 302) \mathrm{O})[\mathrm{O}-1) \mathrm{OC}$ & 0.819 & 0.696 & 1.515 & 1 \\
\hline $\mathrm{COc} 1 \mathrm{cc} 2 \mathrm{c}(\mathrm{c}(\mathrm{c} 1 \mathrm{OC})[\mathrm{O}-]) \mathrm{C}(=\mathrm{O}) \mathrm{C}[\mathrm{C} @ @ \mathrm{H}](\mathrm{O} 2) \mathrm{c} 3 \mathrm{ccc}(\mathrm{cc} 3) \mathrm{O}$ & 0.79 & 0.723 & 1.513 & 1 \\
\hline COc1cc (c2c (c1)O[C@H] $(\mathrm{CC} 2=\mathrm{O}) \mathrm{c} 3 \operatorname{ccc}(\operatorname{cc} 3) \mathrm{O})[$ & 0.839 & 0.666 & 1.505 & 1 \\
\hline $\operatorname{clcc}(\mathrm{c}(\operatorname{cc1} 2 \mathrm{c} c(\mathrm{c}(=\mathrm{O}) \mathrm{c} 3 \mathrm{ccc}(\mathrm{cc} 3 \mathrm{o} 2) \mathrm{O})[\mathrm{O}-]) \mathrm{O}) \mathrm{O}$ & 0.955 & 0.754 & 1.709 & 2 \\
\hline $\mathrm{clcc}(\mathrm{c}(\operatorname{cc} 1 \mathrm{c} 2 \mathrm{c}(\mathrm{c}(=\mathrm{O}) \mathrm{c} 3 \mathrm{c}(\mathrm{cc}(\mathrm{cc} 3 \mathrm{o} 2) \mathrm{O})[\mathrm{O}-])[\mathrm{O}-]) \mathrm{O}) \mathrm{O}$ & 0.941 & 0.754 & 1.695 & 2 \\
\hline $\operatorname{clcc}(\mathrm{c}(\operatorname{cc} 1 \mathrm{c} 2 \mathrm{cc}(=\mathrm{O}) \mathrm{c} 3 \mathrm{c}(\mathrm{cc}(\mathrm{cc} 3 \mathrm{o} 2) \mathrm{O})[\mathrm{O}-]) \mathrm{O}) \mathrm{O}$ & 0.942 & 0.741 & 1.683 & 2 \\
\hline $\mathrm{COc1ccc}(\mathrm{cc} 1 \mathrm{O})[\mathrm{C} @ \mathrm{H}] 2[\mathrm{C} @ @ \mathrm{H}](\mathrm{C}(=\mathrm{O}) \mathrm{c} 3 \mathrm{c}(\mathrm{cc}(\mathrm{cc} 3 \mathrm{O} 2) \mathrm{OC})[\mathrm{O}-]) \mathrm{O}$ & 0.946 & 0.706 & 1.652 & 2 \\
\hline $\mathrm{COc} 1 \mathrm{ccc}(\mathrm{cc} 1) \mathrm{c} 2 \mathrm{cc}(=\mathrm{O}) \mathrm{c} 3 \mathrm{c}(\mathrm{cc}(\mathrm{cc} 3 \mathrm{o} 2) \mathrm{O})[\mathrm{O}-]$ & 0.888 & 0.755 & 1.643 & 2 \\
\hline COc1ccc $(\operatorname{cc} 1 \mathrm{O}) \mathrm{c} 2 \mathrm{c}(\mathrm{c}(=\mathrm{O}) \mathrm{c} 3 \mathrm{c}(\mathrm{o} 2) \mathrm{cc}(\mathrm{c}(\mathrm{c} 3[\mathrm{O}-]) \mathrm{O}) \mathrm{O})[\mathrm{O}-]$ & 0.922 & 0.706 & 1.628 & 2 \\
\hline $\mathrm{COc} 1 \mathrm{cc}(\mathrm{c} 2 \mathrm{c}(=\mathrm{O}) \mathrm{cc}(\mathrm{oc} 2 \mathrm{c} 1) \mathrm{c} 3 \mathrm{ccc}(\mathrm{c}(\mathrm{c} 3) \mathrm{OC}) \mathrm{O})[\mathrm{O}-]$ & 0.903 & 0.711 & 1.614 & 1 \\
\hline $\mathrm{COc} 1 \mathrm{ccc}(\mathrm{cc} 1) \mathrm{c} 2 \mathrm{cc}(=\mathrm{O}) \mathrm{c} 3 \mathrm{c}(\mathrm{cc}(\mathrm{cc} 3 \mathrm{O} 2) \mathrm{OC})[\mathrm{O}-]$ & 0.875 & 0.732 & 1.607 & 1 \\
\hline $\operatorname{COc} 1 \mathrm{c}(=\mathrm{O}) \mathrm{c} 2 \mathrm{c}(\mathrm{cc}(\operatorname{cc} 2 \mathrm{oc} 1 \mathrm{c} 3 \mathrm{ccc}(\mathrm{c}(\mathrm{c} 3) \mathrm{O}) \mathrm{O}) \mathrm{O})[\mathrm{O}-]$ & 0.897 & 0.707 & 1.604 & 1 \\
\hline COc1cc $(\mathrm{c} 2 \mathrm{c}(\mathrm{c} 1) \mathrm{oc}(\mathrm{c}(\mathrm{c} 2=\mathrm{O})[\mathrm{O}-]) \mathrm{c} 3 \mathrm{ccc}(\mathrm{c}(\mathrm{c} 3) \mathrm{OC}) \mathrm{O})[\mathrm{O}-]$ & 0.889 & 0.71 & 1.599 & 1 \\
\hline $\mathrm{COc} 1 \mathrm{ccc}(\mathrm{cc} 1 \mathrm{O}) \mathrm{c} 2 \mathrm{c}(\mathrm{c}(=\mathrm{O}) \mathrm{c} 3 \mathrm{c}(\mathrm{cc}(\mathrm{cc} 3 \mathrm{o} 2) \mathrm{OC})[\mathrm{O}-]) \mathrm{OC} \mathrm{O}-]$ & 0.92 & 0.674 & 1.594 & 1 \\
\hline $\mathrm{COc} 1 \mathrm{cc} 2 \mathrm{c}(\mathrm{c}(\mathrm{c} 1 \mathrm{OC})[\mathrm{O}-]) \mathrm{c}(=\mathrm{O}) \mathrm{c}(\mathrm{c}(\mathrm{o} 2) \mathrm{c} 3 \mathrm{ccc}(\mathrm{c}(\mathrm{c} 3) \mathrm{O}) \mathrm{O}) \mathrm{OC}$ & 0.849 & 0.656 & 1.505 & 1 \\
\hline $\mathrm{CC}(=\mathrm{CCc} 1 \mathrm{cc}(\operatorname{ccc} 1 \mathrm{O})[\mathrm{C} @ @ \mathrm{H}] 2 \mathrm{CC}(=\mathrm{O}) \mathrm{c} 3 \mathrm{ccc}(\mathrm{cc} 3 \mathrm{O} 2) \mathrm{O}) \mathrm{C}$ & 0.849 & 0.653 & 1.502 & 1 \\
\hline $\mathrm{COc} 1 \mathrm{ccc}(\mathrm{cc} 1) \mathrm{c} 2 \mathrm{c}(\mathrm{c}(=\mathrm{O}) \mathrm{c} 3 \mathrm{c}(\mathrm{cc}(\mathrm{cc} 3 \mathrm{o} 2) \mathrm{OC})[\mathrm{O}-]) \mathrm{OC}$ & 0.816 & 0.684 & 1.5 & 1 \\
\hline $\mathrm{c} 1 \mathrm{cc}(\mathrm{ccclc} 2 \mathrm{c}(\mathrm{c}(=\mathrm{O}) \mathrm{c} 3 \mathrm{c}(\mathrm{cc}(\mathrm{cc} 3 \mathrm{o} 2) \mathrm{O})[\mathrm{O}-1)[\mathrm{O}-1) \mathrm{O}$ & 0.812 & 0.68 & 1.492 & 1 \\
\hline $\mathrm{COc} 1 \mathrm{cc}(\mathrm{c}(\mathrm{c}(\mathrm{c} 1 \mathrm{O}) \mathrm{OC}) \mathrm{OC}) \mathrm{c} 2 \mathrm{cc}(=\mathrm{O}) \mathrm{c} 3 \mathrm{c}(\mathrm{cc}(\mathrm{cc} 3 \mathrm{o} 2) \mathrm{O})[\mathrm{O}-]$ & 0.819 & 0.663 & 1.482 & 1 \\
\hline $\mathrm{CC}(=\mathrm{CCc} 1 \mathrm{cc}(\operatorname{ccc} 1 \mathrm{O}) / \mathrm{C}=\mathrm{C} / \mathrm{C}(=\mathrm{O}) \mathrm{c} 2 \operatorname{ccc}(\operatorname{cc} 2 \mathrm{O}) \mathrm{O}) \mathrm{C}$ & 0.857 & 0.619 & 1.476 & 1 \\
\hline COc1 ccc $(\mathrm{cc} 1) \mathrm{c} 2 \mathrm{c}(\mathrm{c}(=\mathrm{O}) \mathrm{c} 3 \mathrm{c}(\mathrm{cc}(\mathrm{cc} 3 \mathrm{o} 2) \mathrm{OC})[\mathrm{O}-])[\mathrm{O}-]$ & 0.81 & 0.658 & 1.468 & 1 \\
\hline
\end{tabular}<smiles>O=C1CC(Br)Oc2cc(O)ccc21</smiles><smiles>C=CC</smiles><smiles>[Z19]=C(/C=C/Br)c1ccc(O)cc1O</smiles><smiles>O=c1cc(Br)oc2cc(O)ccc12</smiles>

43

Figure 12. Retrosynthetic pathway for chromanones and chromones 


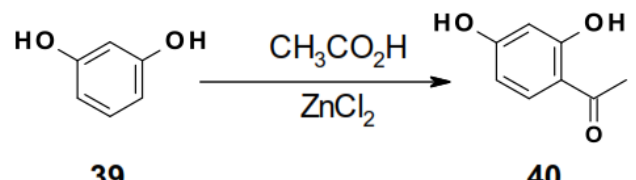

39

40<smiles></smiles>

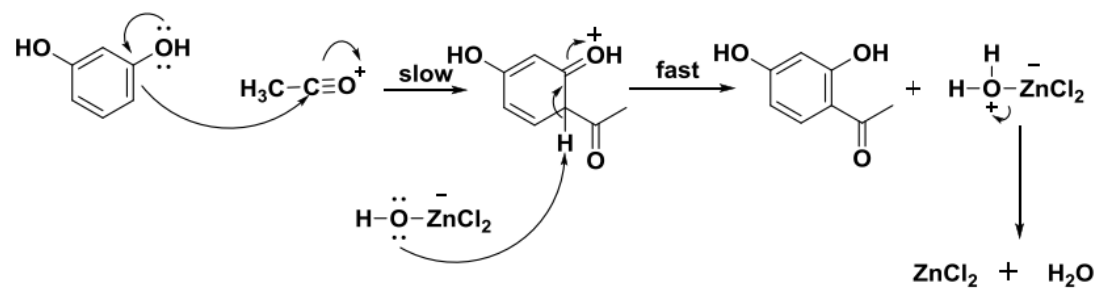

Figure 13. Mechanism of acylation<smiles></smiles>

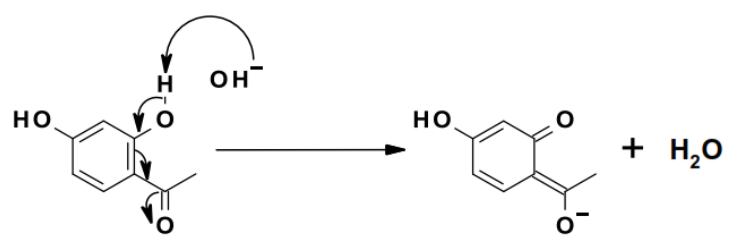

Figure 14. Mechanism of de-protonation of phenolic protons

Synthesis of 2',4'-dihydroxy-4-chlorochalcone (47). 2',4'-Dihydroxy-4-chlorochalcone (47) was done through base-catalyzed Aldol condensation of 2,4dihydroxyacetophenone (40) and 4-chlorobenzaldeyde (46). Compound 47 was obtained as yellow crystals in $16 \%$ yield. Unlike the previous Aldol condensation, which took place at room temperature, this reaction required refluxing at $70{ }^{\circ} \mathrm{C}$ for $48 \mathrm{hrs}$.

The ${ }^{1} \mathrm{H}$ NMR signals for compound 47 were similar to those of compound $\mathbf{4 0}$ except for the incorporation of two trans olefinic protons at $\delta 8.00\left(d, J=15.5 \mathrm{~Hz}, 1 \mathrm{H}, \mathrm{H}_{\beta}\right)$ and $7.86\left(d, J=15.5 \mathrm{~Hz}, 1 \mathrm{H}, \mathrm{H}_{\alpha}\right)$ and an $\mathrm{AA}^{\prime} \mathrm{BB}^{\prime}$ aromatic spin system resonating at $\delta 7.91(d, J=8.4 \mathrm{~Hz}, 2 \mathrm{H}, \mathrm{C}-2$ and C-6) and $7.52(d, J=8.5 \mathrm{~Hz}, 2 \mathrm{H}, \mathrm{C}-3$ and C-5). In the ${ }^{13} \mathrm{C}$ NMR, the signal for the carbonyl is more shielded $(\delta$ 191.7) compared to the starting material ( $\delta$ 202 .8), consistent with an $\alpha$-unsaturated carbonyl system (121.6 $(\alpha-C)$ and $142.3(\beta-C))$ as would be expected from an Aldol condensation product.
The low yield of chalcones 2', 4'-dihydroxy-4methoxychalcone (45) and 2', 4'-dihydroxy-4chlorochalcone (47) could be due to side reaction (Cannizaro reaction of the aldehydes) which led to the formation of a mixture of more than two products, which necessitated purification through column chromatography. Cannizaro reaction involves the conversion of nonenolizable aldehydes into alcohol and carboxylic acid and takes place in the presence of a strong base. The side products formed, including p-chlorobenzoic acid, were produced in large quantities. Therefore, it prompted the use of an excess of the benzaldehyde to ensure that the 2,4dihydroxyacetophenone was completely consumed in the reaction.

Synthesis of 7-hydroxy-2-(4-methoxyphenyl) chroman4-one (48). The synthesis of 7-hydroxy-2-(4-methoxyphenyl) chroman-4-one (7-hydroxy-4'-methoxyflavanone) (48) was achieved through the acid-catalyzed cyclization of 2',4'dihydroxy-4-methoxychalcone (45). Compound 48 was isolated as a yellow crystalline solid with a $29 \%$ yield. The low yield of compound $\mathbf{4 8}$ is due to the decomposition of the chalcone hence forming mixtures that needed to be purified by column chromatography. Compound 48 was characterized as a flavanone based on its characteristic ${ }^{1} \mathrm{H}$ NMR $\delta$ at $(5.46(d d, 1 \mathrm{H}, J=2.4,13.2 \mathrm{~Hz}, \mathrm{H}-2), 3.09$ ( $d d, J$ $\left.=13.2,16.8 \mathrm{~Hz}, 1 \mathrm{H}, \mathrm{H}-3_{\mathrm{eq}}\right), 2.81(d d, J=16.8,2.4 \mathrm{~Hz}$, $\left.\left.1 \mathrm{H}, \mathrm{H}-3_{\mathrm{ax}}\right)\right)$ and ${ }^{13} \mathrm{C}$ NMR $(\delta 190.5(\mathrm{C}=\mathrm{O}), 79.7(\mathrm{C}-2), 44.0$ (C-3)) peaks. 
An attempt was made to synthesize chromones (flavones) through oxidative cyclization under two different reaction conditions (Ghodile et al. 2012, Venkatachalam et al. 2012), Figure 15, was unsuccessful. Under the circumstances employed in the attempted cyclization, the chalcones decomposed.

\section{In vitro antiplasmodial activity}

In vitro antiplasmodial bioassay of 2',4'-dihydroxy-4methoxychalcone (45), 2',4'-dihydroxy-4-chlorochalcone (47), and 7-hydroxy-2-(4-methoxyphenyl)chroman-4-one (48) against chloroquine-resistant K1 and chloroquinesensitive 3D7 strains of Plasmodium falciparum were conducted using a non-radioactive assay technique, and the results are as shown in Table 4.

Among the compounds tested, 2',4'-dihydroxy-4methoxychalcone (45) showed the highest antiplasmodial activity against both strains. Moderate antiplasmodial activity was observed for compounds $\mathbf{4 7}$ and $\mathbf{4 8}$ against the chloroquine-resistant $\mathrm{K} 1$ strain of $P$. falciparum. 2',4'Dihydroxy-4-methoxychalcone (45), and 7-hydroxy-2-(4methoxyphenyl) chroman-4-one (48) showed strong antiplasmodial activity against the chloroquine-sensitive
3D7 strain of $P$. falciparum. It is worth noting that, from the docking reports, 2',4'-dihydroxy-4-methoxychalcone (45) ranks the best among the three synthesized and assayed compounds which is consistent with the assay results, Table 4 and Figures 16-18.

In conclusion, the first web-based in silico database of natural products from Kenya was successfully generated and named the Mitishamba database. The 157 chromone, chromanone, and chalcone ligands obtained from the Mitishamba database were subjected to structure and ligand-based virtual screening, leading to the identification of three synthetically accessible ligands for synthesis and antiplasmodial assay. The three ligands synthesized and assayed were a chromanone (flavanone), 7-hydroxy-2-(4methoxyphenyl) chroman-4-one (48), and two chalcones, 2',4'-dihydroxy-4-methoxychalcone (45) and 2',4'dihydroxy-4-chlorochalcone (47). Among the compounds synthesized, 2',4'-dihydroxy-4-methoxychalcone (45) showed the highest antiplasmodial activity against chloroquine-sensitive 3D7 and chloroquine-resistant K1 strains of $P$. falciparum with $\mathrm{IC}_{50}$ values of $5.14 \pm 0.70$ and $4.56 \pm 1.66 \mu \mathrm{g} / \mathrm{ml}$, respectively.<smiles>O=Cc1ccc(O)cc1O</smiles>

40<smiles>O=Cc1ccc(Cl)cc1</smiles>

46

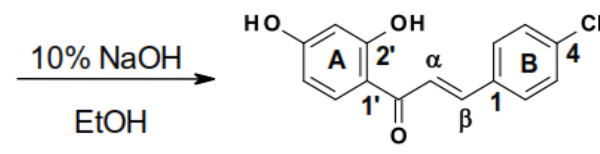

47<smiles>COc1ccc(/C=C/C(=O)c2ccc(O)cc2O)cc1</smiles>

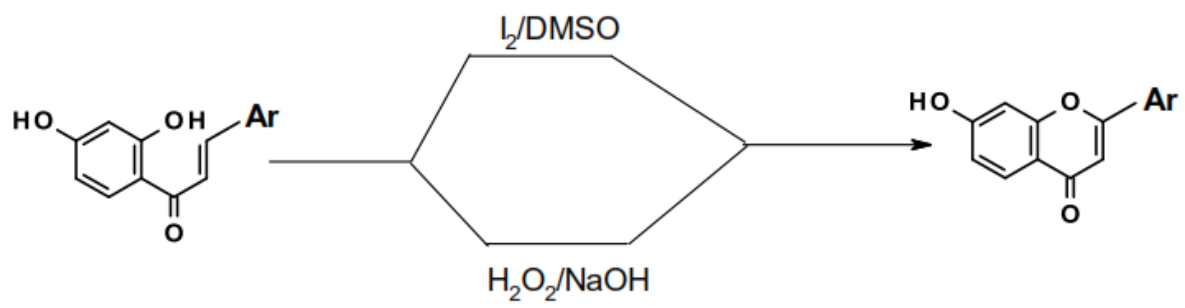

Figure 15. Oxidative cyclization of chalcones to chromones

Table 4. In vitro $\mathrm{IC}_{50}$ values against $\mathrm{K} 1$ and $3 \mathrm{D} 7$ strains of $P$. falciparum

\begin{tabular}{|c|c|c|c|}
\hline \multirow[t]{2}{*}{ Sample } & \multicolumn{2}{|c|}{$\mathrm{IC}_{50}(\mu \mathrm{g} / \mathrm{ml})$} & \multirow{2}{*}{$\begin{array}{c}\text { Docking score } \\
\text { (Kcal/mol) }\end{array}$} \\
\hline & K1 & 3D7 & \\
\hline 2',4'-Dihydroxy-4-methoxychalcone (45) & $4.56 \pm 1.66$ & $5.14 \pm 0.70$ & -14.60 \\
\hline 2',4'-Dihydroxy-4-chlorochalcone (47) & $20.36 \pm 2.77$ & & -14.14 \\
\hline 7-Hydroxy-2-(4-methoxyphenyl) chroman-4-one (48) & $18.01 \pm 2.28$ & $4.57 \pm 2.17$ & -13.34 \\
\hline Chloroquine* & $0.471 \pm 0.037$ & $0.006 \pm 0.0022$ & \\
\hline Mefloquine* & $0.004 \pm 0.0025$ & $0.0008 \pm 0.0004$ & \\
\hline
\end{tabular}

Note: *standard 


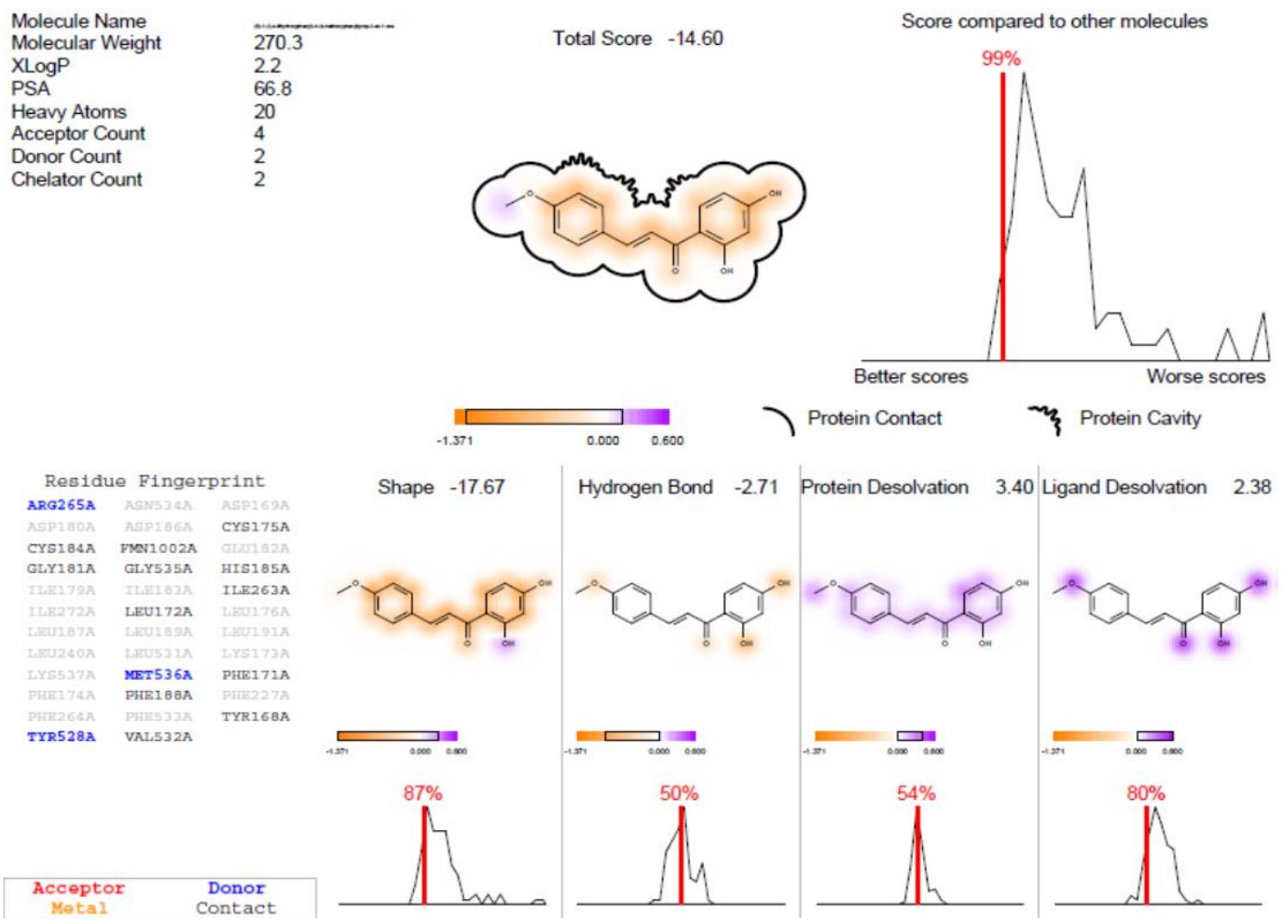

Figure 16. Docking report for 2', 4'-dihydroxy-4-methoxychalcone (45)

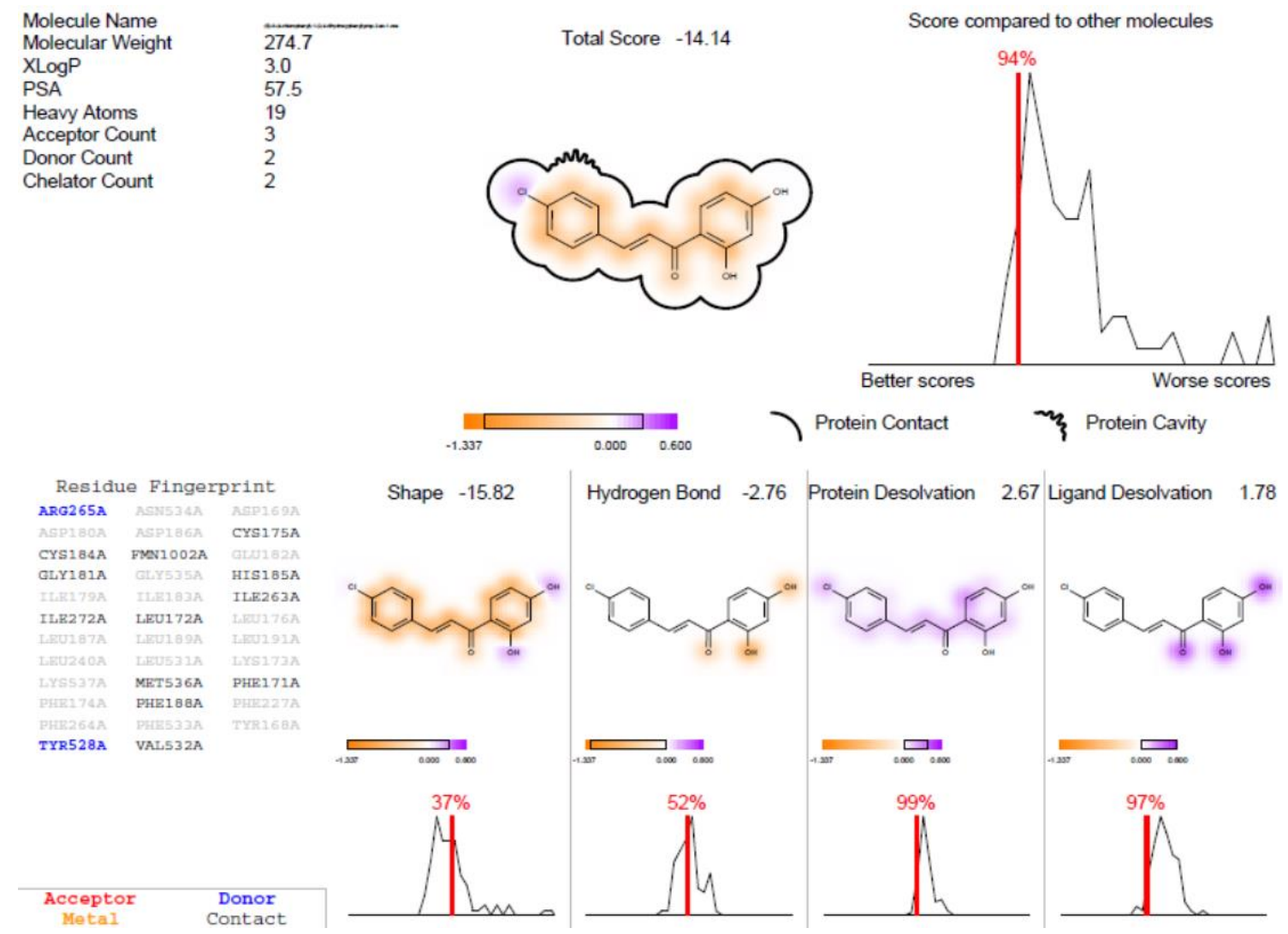

Figure 17. Docking report for 2', 4'-dihydroxy-4-chlorochalcone (47) 


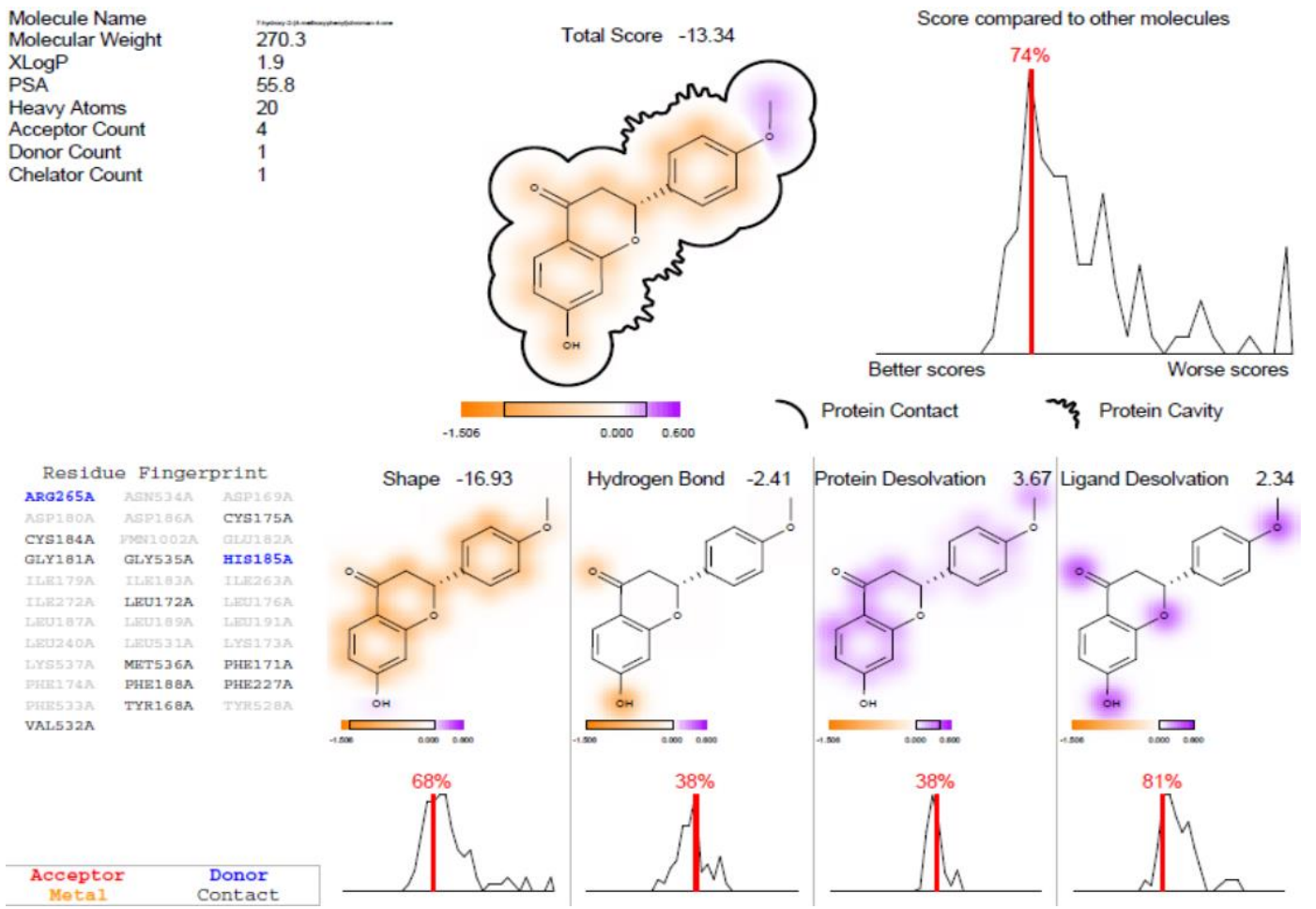

Figure 18. Docking report for 7-hydroxy-2-(4-methoxyphenyl) chroman-4-one (48)

\section{REFERENCES}

Biamonte MA, Wanner J, Le Roch KG. 2013. Recent advances in malaria drug discovery. Bioorg Med Chem Lett 23 (10): 2829-2843.

Bienfait B, Ertl P. 2013. JSME: a free molecule editor in JavaScript. J Cheminform 5 (1): 1-6.

Derese S, Yenesew A, Midiwo JO, Heydenreich M, Peter MG. 2003. A new isoflavone from stem bark of Millettia dura. Bull Chem Soc Ethiopia 17 (1): 113-115.

Dike IP, Obembe OO, Adebiyi FE. 2012. Ethnobotanical survey for potential anti-malarial plants in south-western Nigeria. $J$ Ethnopharmacol 144 (3): 618-626.

Endale M, Alao J, Akala H, Rono N, Eyase F, Derese S, Yenesew A. 2012. Antiplasmodial quinones from Pentas longiflora and Pentas lanceolata. Planta Medica 78 (1): 31-35.

Gaspar A, Silva T, Yáñez M, Vina D, Orallo F, Ortuso F, Borges F. 2011. Chromone, a privileged scaffold for the development of monoamine oxidase inhibitors. J Med Chem 54 (14): 5165-5173.

Ghodile NG, Rajput PR, Banewar V, Raut AR. 2012. Synthesis and antimicrobial activity of some chalcones and flavones having 2 hydroxy acetophenone moiety. Intl J Pharm Biol Sci 3 (3): 389-395.

Gumula I, Heydenreich M, Derese S, Ndiege IO, Yenesew A. 2012. Four isoflavanones from the stem bark of Platycelphium voënse. Phytochem Lett 5 (1): 150-154.

Haider N. 2010. Functionality pattern matching as an efficient complementary structure/reaction search tool: an open-source approach. Molecules 15 (8): 5079-5092.

Heydenreich M, Muiva LM, Eyase FL, Akala HM, Wanyama PJ Yenesew A. 2011. Terpurinflavone: An antiplasmodial flavone from the stem of Tephrosia purpurea. Phytochem Lett 4: 176-178.

Hurt DE, Sutton AE, Clardy J. 2006a. Brequinar derivatives and speciesspecific drug design for dihydroorotate dehydrogenase. Bioorg Med Chem Lett 16 (6): 1610-1615.

Hurt DE, Widom J, Clardy J. 2006b. Structure of Plasmodium falciparum dihydroorotate dehydrogenase with a bound inhibitor. Acta Crystallographica Sect D Biol Crystallogr 62: 312-323.

Jain AN, Nicholls A. 2008. Recommendations for evaluation of computational methods. J Computer-Aided Mol Design 22 (3-4): 133-139.

Keri RS, Budagumpi S, Pai RK, Balakrishna RG. 2014. Chromones as a privileged scaffold in drug discovery: A review. Eur J Med Chem 78: 340-374.
Kokwaro J. 2009. Medicinal Plants of East Africa. 3rd ed. Univ. of Nairobi Press, Nairobi, Kenya.

Lipinski CA, Lombardo F, Dominy BW, Feeney PJ. 2012. Experimental and computational approaches to estimate solubility and permeability in drug discovery and development settings. Adv Drug Deliv Rev 64: 4-17.

Nogueira CR, Lopes LMX. 2011. Antiplasmodial natural products. Molecules 16 (12): 2146-2190.

Omosa LK, Midiwo JO, Derese S, Yenesew A, Peter MG, Heydenreich M. 2010. Neo-Clerodane diterpenoids from the leaf exudate of Dodonaea angustifolia. Phytochem Lett 3 (4): 217-220.

Patil RB, Sawant SD, Thombare PA. 2012. Design, synthesis, and pharmacological evaluation of chromenones and related analogues. Intl J PharmTech Research 4 (1): 375-381.

Schlitzer M. 2007. Malaria chemotherapeutics. Part I: History of antimalarial drug development, currently used therapeutics, and drugs in clinical development. Chem Med Chem 2 (7): 944-986.

Senger M, Rice P, Oinn T. 2003. Soaplab-a unified Sesame door to analysis tools. In: Proceedings of the UK e-Science All Hands Meeting 18: 509-513.

Swann SL, Brown SP, Muchmore SW, Patel H, Merta P, Locklear J, Hajduk PJ. 2011. A unified, probabilistic framework for structure-and ligand-based virtual screening. J Med Chem 54 (5): 1223-1232.

Venkatachalam H, Nayak Y, Jayashree BS. 2012. Evaluation of the antioxidant activity of novel synthetic chalcones and flavonols. Intl $\mathrm{J}$ Chem Eng Appl 3 (3): 216-219.

Yenesew A, Derese S, Midiwo JO, Bii CC, Heydenreich M, Peter MG. 2005. Antimicrobial flavonoids from the stem bark of Erythrina burttii. Fitoterapia 76 (5): 469-472.

Yenesew A, Derese S, Midiwo JO, Oketch-Rabah HA, Lisgarten J, Palmer R, Waters NC. 2003. Anti-plasmodial activities and X-ray crystal structures of rotenoids from Millettia usaramensis subsp. usaramensis. Phytochem 64 (3): 773-779.

Yenesew A, Induli M, Derese S, Midiwo JO, Heydenreich M, Peter MG, Waters NC. 2004. Anti-plasmodial flavonoids from the stem bark of Erythrina abyssinica. Phytochemistry 65 (22): 3029-3032.

Yenesew A, Twinomuhwezi H, Kabaru JM, Akala HM, Kiremire BT, Heydenreich M, Walsh DS. 2009. Antiplasmodial and larvicidal flavonoids from Derris trifoliata. Bull Chem Soc Ethiopia 23 (3): 409-414.

Zhu F, Shi Z, Qin C, Tao L, Liu X, Xu F, Chen Y. 2012. Therapeutic target database update 2012: a resource for facilitating target-oriented drug discovery. Nucleic Acids Res 40 (D1): D1128-D1136. 